\title{
Circulation and environmental conditions during a toxigenic Pseudo-nitzschia australis bloom in the Santa Barbara Channel, California
}

\author{
Clarissa R. Anderson ${ }^{1, *}$, Mark A. Brzezinski ${ }^{1}{ }^{\text {Libe Washburn }}{ }^{2}$, Raphael Kudela ${ }^{3}$ \\ ${ }^{1}$ Marine Science Institute and Department of Ecology, Evolution, and Marine Biology, and ${ }^{2}$ Institute for Computational \\ Earth System Science and Department of Geography, University of California at Santa Barbara, Santa Barbara, \\ California 93106, USA \\ ${ }^{3}$ Ocean Sciences Department, University of California at Santa Cruz, Santa Cruz, California 95064, USA
}

\begin{abstract}
During May 2003, a toxigenic bloom of the diatom Pseudo-nitzschia australis occurred in the Santa Barbara Channel (SBC), California, that was linked to a marine mammal mortality event in the region. Satellite imagery revealed the presence of the bloom prior to a period of strong, spring upwelling along the continental shelf of the SBC. Following upwelling the bloom increased in areal extent to cover most of the SBC. P. australis abundance ranged from $0.4 \times 10^{5}$ to $2 \times 10^{6}$ cells $^{-1}$ with particulate domoic acid (DA) concentrations between 32 and $1684 \mathrm{ng} \mathrm{l}^{-1}$. Significant negative correlations between silicic acid, $\mathrm{Si}(\mathrm{OH})_{4}: \mathrm{NO}_{3}{ }^{-}$and $\mathrm{Si}(\mathrm{OH})_{4}: \mathrm{PO}_{4}{ }^{3-}$ ratios and particulate DA suggest that the bloom may have been experiencing Si limitation. High cell abundance and the highest levels of cellular DA ( 0.14 to $2.1 \mathrm{pg} \mathrm{cell}^{-1}$ ) were associated with a cyclonic eddy in the western end of the SBC. Cyclonic eddies within the SBC are known to be convergent, and may thus have concentrated $P$. australis cells within this feature. Propagation of the eddy transported the bloom to the west, indicating that coherent circulation features may help predict the fate of harmful algal blooms in coastal systems.
\end{abstract}

KEY WORDS: Domoic acid $\cdot$ Pseudo-nitzschia spp. P Pseudo-nitzschia australis $\cdot$ Cyclonic eddy · Upwelling $\cdot$ Bio-physical coupling $\cdot$ Southern California Bight

\section{INTRODUCTION}

The Southern California Bight has historically been a region of few nuisance phytoplankton blooms, but blooms of the pennate diatom genus Pseudo-nitzschia have become frequent in recent years. Although toxin production is rare in diatoms, several species of Pseudo-nitzschia can synthesize the toxin domoic acid (DA), which bio-accumulates in shellfish and finfish (Fritz et al. 1992, Garrison et al. 1992). Once consumed by mammals, DA replaces a crucial neurotransmitter, resulting in deleterious health effects and causing amnesic shellfish poisoning in humans (Buck et al. 1992, Fritz et al. 1992, Bates et al. 1998). While Pseudo-nitzschia spp. have long been recorded in surveys of phytoplankton species composition for the Southern Cali- fornia Bight (Allen 1922, Fryxell et al. 1997, Busse et al. 2006), the apparent recent rise in cell abundance and toxigenic events in this region parallels recent worldwide increases in harmful algal bloom frequency (Smayda 1990, 1992, Hallegraeff 1993). In 1998, the entire west coast of California experienced significant impacts to marine life due to extensive blooms of $P$. australis and $P$. multiseries that were recorded from Monterey Bay (36 ${ }^{\circ} \mathrm{N}$ latitude) to Santa Barbara (34 ${ }^{\circ} \mathrm{N}$ latitude) (Scholin et al. 2000, Trainer et al. 2000). In the spring of 2002 and 2003, 2 blooms of Pseudo-nitzschia spp. in the Santa Barbara Channel (SBC) resulted in $>1500$ pinniped deaths (Langlois 2003, 2004) and raised questions regarding the causes of local toxic events.

Dominance of Pseudo-nitzschia spp. over other diatom species may be related to their nutrient physio- 
logy. Like many diatoms, Pseudo-nitzschia spp. grow rapidly in high-Si regimes (Egge \& Aksnes 1992, cf. Bates et al. 1998) and their blooms have been associated with upwelling and high levels of new nutrients off the coasts of California and Washington states (Bates et al. 1998, Adams et al. 2000, Trainer et al. 2002, Marchetti et al. 2004). There is also evidence that Pseudo-nitzschia spp. are superior competitors for silicic acid. P. pungens (Grunow) was able to outcompete other diatoms at low $\mathrm{Si}(\mathrm{OH})_{4}: \mathrm{NO}_{3}{ }^{-}$ratios in mixed culture (Sommer 1994) and natural blooms of Pseudonitzschia spp. have been repeatedly observed in association with depleted silicic acid concentrations (Dortch et al. 1997, Bates et al. 1998, Marchetti et al. 2004) and low $\mathrm{Si}(\mathrm{OH})_{4}: \mathrm{NO}_{3}{ }^{-}$ratios (Marchetti et al. 2004).

Laboratory experiments with various Pseudo-nitzschia spp. have shown that the production of DA can occur as a stress response to limiting macronutrients such as silicic acid (Pan et al. 1996a,b, 1998, Kudela et al. 2003b, Fehling et al. 2004) and/or to micronutrient limitation (Maldonado et al. 2002, Wells et al. 2005). Field observations of the association between high DA levels and Si limitation have further strengthened hypotheses that silicic acid supply, in particular, is a determinant of toxin production during Pseudo-nitzschia spp. blooms (Kudela et al. 2003a, Marchetti et al 2004). It is not clear, however, if there is a threshold concentration of silicic acid below which DA production is triggered. Rather, Pan et al. (1996b) suggested that $P$. multiseries has a biphasic response to decreasing silicic acid concentrations-one manifested at intermediate $\mathrm{Si}(\mathrm{OH})_{4}$ levels that is induced by modest physiological stress, and the other triggered by severe Si limitation - both of which lead to increased DA production.

A dominant source of new nutrients that support phytoplankton blooms in the SBC is wind-driven upwelling. Regional geography causes upwelling within the SBC to be decoupled from that occurring along most of the west coast of North America. Along the north-south oriented coast of central and northern California, strong northwesterly winds drive intense upwelling during spring and summer, but at the western end of the SBC at Point Conception (see Fig. 1), the mainland coast turns eastward such that water movement over the east-west oriented SBC shelf is driven more by spatially variable wind fields and sea-level gradients than by the prevailing northwesterly winds (Harms \& Winant 1998). Ekman upwelling can occur within the SBC when winds blow from the west. Thus, the SBC is influenced by upwelling in 2 ways: (1) water upwelled at or to the north of Point Conception by northwesterly winds can be advected into the channel, and (2) westerly winds can drive upwelling within the channel itself.
Upwelling is 1 of 3 dominant synoptic circulation states in the SBC: upwelling, relaxation, and convergent (Harms \& Winant 1998). The upwelling mode is responsible for most of the variance in phytoplankton biomass, with the largest blooms occurring in spring, as revealed from time series analyses of satellite chlorophyll concentrations and sea surface temperature in the SBC (Otero \& Siegel 2004). The relaxation and convergent modes are characterized by a recurring anti-clockwise turning of the flow field centered over the Santa Barbara Basin in the western SBC (Harms \& Winant 1998, Oey et al. 2001, Winant et al. 2003), and at times this circulation closes to form an eddy which spans most of the western channel. This recurrent feature extends down to at least $200 \mathrm{~m}$ (Nishimoto \& Washburn 2002) and maintains a convergent surface circulation (Beckenbach 2004) that is capable of concentrating plankton (Nishimoto \& Washburn 2002).

We examined the influence of the formation of a cyclonic eddy following a period of strong local upwelling within the SBC on the distribution and toxicity of a bloom of Pseudo-nitzschia spp. in May 2003. The large spatial extent of the bloom offered us the opportunity to examine the relationship between cell abundance, DA distribution, circulation and nutrient concentrations. Our goals were (1) to identify the Pseudo-nitzschia species present, (2) to describe spatial patterns in bloom toxicity and (3) to investigate potential chemical and physical drivers of bloom development, toxicity and transport.

\section{MATERIALS AND METHODS}

The SBC-LTER project conducts cruises 3 times a year in the $\mathrm{SBC}$, focusing water sampling efforts along a 32-station grid which includes a 7 -station transect monitored monthly by the existing Plumes and Blooms (PnB) project (Fig. 1) (see www.icess.ucsb.edu/PnB/ PnB.html). An additional 7-station transect roughly overlapping grid Stns 10 to 14 was sampled on 21 May 2003 in response to the harmful algal bloom (HAB) (Fig. 1). Data were collected from 15 to 22 May 2003 (Fig. 2) aboard the RV 'Point Sur'. Towed profiles were collected with a Scanfish Mk II undulating profiler fitted with an SBE 9 CTD and a WetLabs C-star fluorometer from 15 to 16 May (Fig. 2). Water samples were collected from 17 to 19 May (Fig. 2) at each station using 121 Niskin bottles fitted to a Sea-Bird Electronics (SBE) rosette equipped with an SBE 9 plus CTD, and a Chelsea Aqua 3 fluorometer. In response to the presence of the harmful algal bloom, we repeated the Scanfish tow from Stns 10 to 14 on 21 and 22 May (Figs. 1 \& 2). 


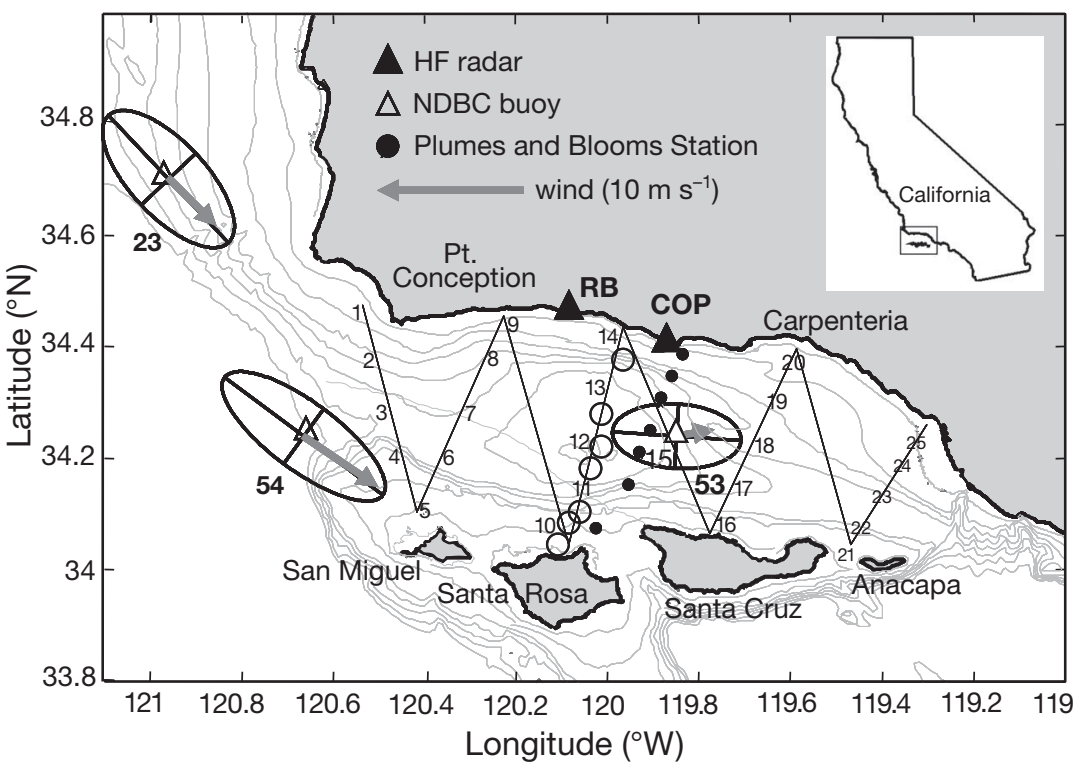

Fig. 1. Study area in the Santa Barbara Channel (SBC), California, which spans ca. $50 \times 100 \mathrm{~km}$. $\mathbf{\Delta}$ : high-frequency $(\mathrm{HF})$ radar sites at Refugio Beach (RB) and Coal Oil Point (COP), with an average coverage range of $60 \mathrm{~km}$; 1 to 25: SBC-LTER grid stations; $\bullet$ : 7 'Plumes and Blooms' stations; $\bigcirc$ : additional harmful algal bloom transect sampled on 21 May; $\triangle$ : National Data Buoy Center Buoys (NDBC) 23, 54 and 53, shown with wind ellipses to indicate variance for principal axes. Vectors are mean wind strength along principal axis and are scaled relative to $10 \mathrm{~m} \mathrm{~s}^{-1}$ representation

filters, which were immediately frozen prior to analysis. Chlorophyll filters were extracted in $90 \%$ acetone for $24 \mathrm{~h}$ at $-20^{\circ} \mathrm{C}$. Fluorescence was measured with and without acidification to determine chlorophyll $a$ and phaeopigment concentrations. HPLC analysis of phytoplankton pigments was carried out by the C. Trees Laboratory at San Diego State University using a modified JGOFS protocol (Bidigare et al. 2003). We filtered 11 of seawater through a Whatman GF/F glass fiber filter, and then froze the particulate matter and filter in liquid nitrogen until extraction in 94\% acetone for $24 \mathrm{~h}$ at $0^{\circ} \mathrm{C}$. Pigment concentrations were determined by a ternary gradient system using HPLC-grade solvents and a reverse-phase HPLC column (Bidigare et al. 2003).

Primary productivity was measured using water samples collected at $5 \mathrm{~m}$ for all LTER grid stations and at 7 depths for all PnB stations, using a modified JGOFS ${ }^{14} \mathrm{C}$ method. Sampling depths on the 7-depth profiles were chosen to correspond to 100 , $54,35,16,7,3.6$ and $1.7 \%$ of the surface photosynthetically active radiation (PAR) light level $\left(I_{0}\right)$ measured just below the sea

During Scanfish tows, water samples for chlorophyll $a$ and inorganic nutrients concentrations were collected from the ship's clean seawater intake $(\sim 3 \mathrm{~m}$ depth). During CTD/rosette casts at each LTER grid station, water samples were collected from 7 discrete depths to $75 \mathrm{~m}$ for determination of chlorophyll $a$ and dissolved inorganic nutrient concentrations. All collection procedures were in accordance with the techniques recommended by the US JGOFS (Knap et al. 1993). All samples were unreplicated. Dissolved inorganic nutrient analyses were performed by the UCSB Marine Science Institute's Analytical Laboratory using flow injection techniques (Johnson et al. 1985) on a QuickChem 8000 (Lachat Instruments Division, Zellweger Analytics) on seawater stored frozen in 20-ml plastic scintillation vials. Detection limits for nitrate $\left(\mathrm{NO}_{3}{ }^{-}\right)$, orthophosphate $\left(\mathrm{PO}_{4}{ }^{3-}\right)$, and silicic acid $\left(\mathrm{Si}(\mathrm{OH})_{4}\right)$ were $0.1,0.05$ and $0.2 \mu \mathrm{M}$, respectively. Ammonium concentrations measured for the region by the SBC-LTER are consistently very close to analytical detection limits on the flow injection system, hence $\left[\mathrm{NH}_{4}{ }^{+}\right]$was not included in this study.

Chlorophyll $a$ and phaeopigment analyses were performed with a Turner Designs 10AU digital fluorometer following standard JGOFS procedures. For chlorophyll a analysis, $250 \mathrm{ml}$ of raw seawater were filtered through Millipore HAWP $45 \mathrm{~mm}$ cellulose surface. Each sample was divided between two $250 \mathrm{ml}$ acid-cleaned polycarbonate bottles. Then ${ }^{14} \mathrm{C}$-labeled $\mathrm{HCO}_{3}{ }^{-}$(approx. $8 \mu \mathrm{Ci}$ per sample) was added to each aliquot and all bottles were placed in deck incubators equipped with flowing surface seawater to maintain temperature. We incubated 1 bottle from each pair in darkness, while the second bottle was incubated beneath neutral density screening to simulate the light intensity at the depth from which the sample was collected. For the $5 \mathrm{~m}$ samples from the grid stations, all light bottles were incubated at the $50 \%$ light level. At the end of incubation, particulates were collected on $\mathrm{GF} / \mathrm{F}$ filters and radioactivity (dpm) was measured with a Beckman 5801 scintillation counter after acidification to remove excess radiolabeled bicarbonate and the addition of a scintillation cocktail (Optima Gold $\mathrm{XR}$ ). Total radioactivity was determined on $100 \mu \mathrm{l}$ of incubated seawater in the same scintillation cocktail after the addition of $\beta$-phenethylamine to prevent radiolabeled inorganic $\mathrm{CO}_{2}$ from escaping to the atmosphere. Final primary productivity values were calculated as the difference between productivities in the light and dark bottles for each sample. Carbon assimilation number $\left(P^{B}\right)$, an approximate assessment of photosynthetic efficiency, is defined as the carbon assimilation rate $\left(\mathrm{mg} \mathrm{C} \mathrm{m} \mathrm{m}^{-3} \mathrm{~d}^{-1}\right)$ per unit chlorophyll a $(\mathrm{mg}$ $\mathrm{m}^{-3}$ ) and is given in units of $\mathrm{mg} \mathrm{C} \cdot \mathrm{mg} \mathrm{chl}^{-1} \mathrm{~d}^{-1}$. 
Principal axis winds

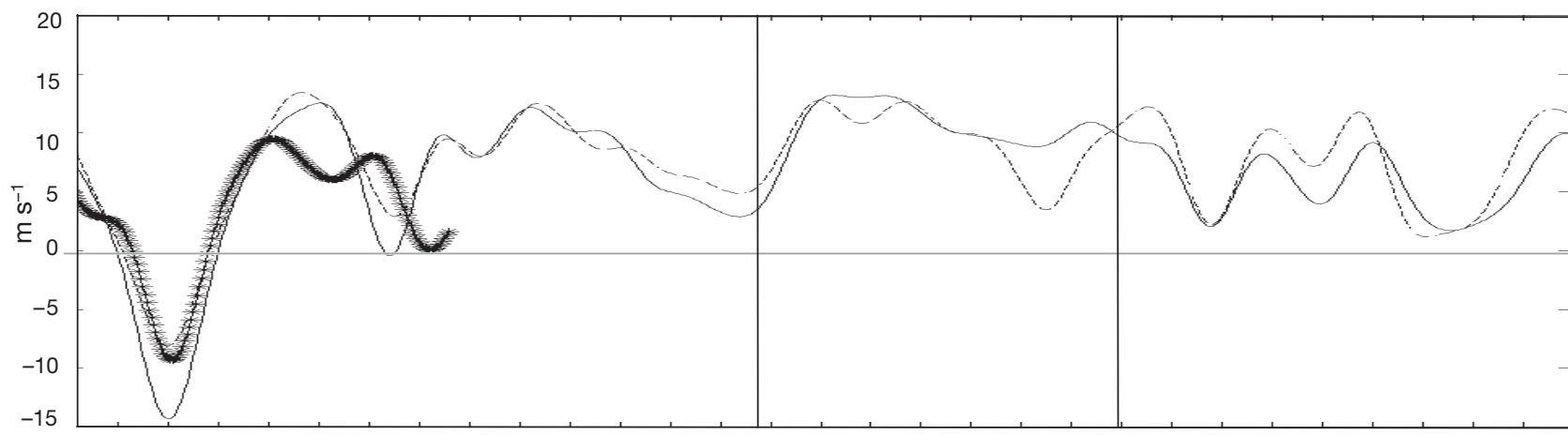

HF radar maps

AVHRR

(
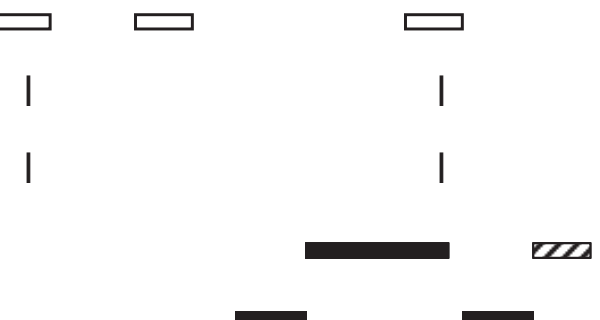

SeaWiFS images

I

(20)

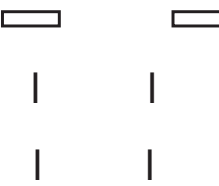

CTD grid

Scanfish surveys
$\begin{array}{llll}01 & 02 & 03 & 04\end{array}$
$\begin{array}{lllllll}05 & 06 & 07 & 08 & 09 & 10 & 11\end{array}$
$\begin{array}{lllll}11 & 12 & 13 & 14 & 15\end{array}$
$15 \quad 16 \quad 17$
May 2003

Fig. 2. Upper panel: hourly principal axis wind velocities $\left(\mathrm{m} \mathrm{s}^{-1}\right)$ for NDBC Buoys $23(-), 54(-----)$, and $53(\rightarrow<)$; coverage for mid-channel Buoy 53 was restricted to beginning of the month. Winds have been low-pass filtered with a cutoff frequency of $1 / 36 \mathrm{~h}^{-1}$. Directions of principal axes are shown in Fig. 1, and vertical bars indicate sampling period (15 to $22 \mathrm{May}$, bold). Lower panel: Timeline of shipboard sampling, available SeaWiFS images, and selected HF radar images of surface currents for May 2003. Black horizontal bars: CTD grid survey (16 to 20 May) and Scanfish (undulating profiles) surveys (15 to 16, 20 and 21 May); hatched bar: CTD casts and water sampling in response to harmful algal bloom (21 and 22 May); open bars for HF radar maps: $24 \mathrm{~h}$ averages for dates specified

Whole water samples $(125 \mathrm{ml})$ were collected from $5 \mathrm{~m}$ within the mixed layer at each grid station and from the 7 stations along the HAB transect (Fig. 1). Water collected along the PnB transect was not used for phytoplankton counts. Samples were preserved in $37 \%$ formalin (Bouin's solution with picric acid; Fisher Scientific) at a final concentration of $2 \%$ for phytoplankton cell counts, using the Utermöhl method for the inverted microscope (Hasle 1978). Aliquots were settled in 10 and $25 \mathrm{ml}$ settling chambers for ca. $24 \mathrm{~h}$. Cells $>5 \mu \mathrm{m}$ in length were quantified and identified at $\times 320$ magnification, and the abundance of Pseudo-nitzschia was determined to the genus level. Scanning electron microscopy (SEM) of whole water samples (Miller \& Scholin 2000) was used to establish the proportion of Pseudo-nitzschia spp. that was potentially toxic. Briefly, $5 \mathrm{ml}$ of preserved whole water samples were filtered onto $1.2 \mu \mathrm{m}$ Millipore polycarbonate filters $(13 \mathrm{~mm})$ and cleaned with saturated $\mathrm{KMnO}_{4}$. After filtering, the phytoplankton cells and polycarbonate filter membranes were mounted to an aluminum stage using conductive carbon tape, sputter-coated with gold, and examined at $20 \mathrm{kV}$ with a Tescan Vega TS 5130MM scanning electron microscope.

Particulate DA analysis was performed on samples collected from $5 \mathrm{~m}$ at each the $25 \mathrm{grid}$ stations and additional 7 -station HAB transect, excluding the PnB transect (Fig. 1). For each sample, $500 \mathrm{ml}$ of seawater were filtered through a Millipore GF/F $25 \mathrm{~mm}$ glass fiber filter, immediately frozen in liquid nitrogen and then transferred to a $-70^{\circ} \mathrm{C}$ freezer for storage. HPLC analysis of DA concentrations was done using FMOC$\mathrm{Cl}$ reagent solution to derivatize domoic acid from microalgal cells and kainic acid as an internal standard (Pocklington et al. 1990, Wright \& Quilliam 1995, R. Kudela pers. comm.). Cellular DA concentrations were derived by normalizing particulate DA to Pseudonitzschia spp. cell abundance and expressed in units of pg DA cell ${ }^{-1}$.

Sea-viewing wide-field-of-view sensor (SeaWiFS) images (see Fig. 3a) for the SBC were obtained from high-resolution picture transmission (HRPT) data (distributed active archive data, Code 902, NASA) and 
processed using operational algorithms (McClain et al. 2004). While retrievals from SeaWiFS chlorophyll a tend to underestimate actual concentrations in the SBC above $1.5 \mu \mathrm{g} \mathrm{l^{-1 }}$, all significant blooms measured as part of the ongoing Plumes and Blooms project have been detected by SeaWiFS $\left(\mathrm{r}^{2}=0.53, \mathrm{n}=154\right)$ (Otero \& Siegel 2004). Advanced very high resolution radiometer, sea surface temperature (AVHRR SST) imagery (see Fig. 3b) for the SBC was obtained from the NOAA Comprehensive Large Array-Stewardship System (CLASS) and processed using the non-linear sea surface temperature (NLSST) algorithm (McClain et al. 1985, 2004).

Maps of surface currents (see Fig. 3c) in the SBC representing $24 \mathrm{~h}$ averages of velocity vectors were obtained from high-frequency (HF) radars (Sea Sondes; CODAR Ocean Sensors) operated at approximately $13 \mathrm{MHz}$ from stations at Refugio Beach (RB), and Coal Oil Point (Fig. 1). These HF radars have a range of $60 \mathrm{~km}$, a radial resolution of $1.5 \mathrm{~km}$, and azimuthal resolution of $5^{\circ}$. Vectors were interpolated onto a $2 \mathrm{~km}$ square grid and, at each grid point, spatial averages were computed over circles $3 \mathrm{~km}$ in radius. Emery et al. (2004) has described HF radar operation and data processing in more detail.

National Data Buoy Center (NDBC) Buoys 46053, 46054 and 46023 (hereafter Buoys 53, 54 and 23, respectively) record hourly wind velocities (Fig. 1) in the study area, and these were used to assess when upwelling-favorable conditions were present in the SBC. Mean winds were equatorward and nearly parallel to the coast at all 3 buoy locations (Fig. 1). Similarly, examination of the residual winds (true wind minus mean wind) showed that the principle axis of variability about the mean wind was also oriented in an alongshore direction at each site (Fig. 1). This allowed us to use the component of the true wind that lies along the principle axis of wind variation as an upwelling index at each site, with positive values favoring upwelling along the mainland coast and negative values favoring downwelling (Fig. 2).

Contour plots of physical, chemical and phytoplankton abundance data were created using kriging functions in MATLAB (Version 5.3, Mathworks). Contours of various parameters measured over 15 to 22 May 2003 are presented at $5 \mathrm{~m}$ to maintain consistency with the data on phytoplankton abundance and DA concentration obtained from this depth. Where duplicate samples existed for a given station, we used the average value. We calculated the depth of the mixed layer in each CTD profile using a change in potential temperature of $0.1^{\circ} \mathrm{C}$ from the surface. All correlation coefficients presented (see Table 1) are from linear correlation analyses performed in Excel (Microsoft Office 2000) and MATLAB (Version 5.3).

\section{RESULTS}

SeaWiFS chlorophyll a images from April (not shown) through May 2003 (Fig. 3a) show elevated chlorophyll a concentrations developing along the mainland and then later extending into the entire channel. These images indicate that a phytoplankton bloom began before 11 May (Fig. 3a) and persisted through the end of the month. We sampled this bloom at what appears to have been its peak, when enhanced chlorophyll a levels were widespread within the SBC (Fig. 3a, 19 May). Wind directions throughout May were upwelling-favorable both in the SBC and at Point Conception (Fig. 2) according to principal axis winds at Buoys 23 and 54 (Fig. 2). Buoy 53 wind velocities were not available for most of May, but winds at this location are usually highly correlated with winds at the other buoys (Fig. 2), making it likely that mid-channel winds drove local upwelling within the SBC during this period. This is corroborated by the 11 May AVHRR SST image, which shows cold surface water throughout the channel with the lowest temperatures located along the mainland coast (Fig. 3b). Chlorophyll a concentrations at this time were high across much of the $\mathrm{SBC}$, with the highest concentrations along the mainland (Fig. 3a).

Cyclonic flow was clearly evident in the western channel from 11 to 31 May (with the possible exception of 23 May) resulting in westward flow along the mainland and eastward flow along the Channel Islands. AVHRR SST imagery from 19 May shows warmer waters along the mainland with colder waters confined to the southwestern region of the SBC (Fig. 3b), suggesting that the persistent cyclonic flow entrained cooler water from off Point Conception into the southwestern region of the channel (Fig. 3a,b). Toward the end of May, the phytoplankton bloom was biased to the west, with a local maximum in chlorophyll a developing within the cyclonic flow of the western channel (Fig. 3a).

Phytoplankton abundance and DA data from $5 \mathrm{~m}$ water samples were deemed to be generally within the active euphotic zone, since the measured \% $\mathrm{I}_{0}$ at $5 \mathrm{~m}$ ranged from 16 to $35 \%$ and the average mixed layer depth for all stations was $8.25 \mathrm{~m}( \pm 7.16 \mathrm{~m})$. Cell counts from the $5 \mathrm{~m}$ samples indicated that bloom levels of Pseudo-nitzschia spp. were present throughout the SBC from 15 to 22 May $\left(5.0 \times 10^{5}\right.$ to $2.4 \times 10^{6}$ cells $\left.^{-1}\right)$. The genus Pseudo-nitzschia numerically comprised $\sim 43$ to $72 \%$ of the phytoplankton assemblage ( $>5 \mu \mathrm{m}$ ) in all light microscopy samples counted $(\mathrm{n}=41)$ and were the dominant diatoms. Concentrations of the diatom-diagnostic pigment fucoxanthin averaged $42 \%$ of the total chlorophyll $a$ at $5 \mathrm{~m}$ and were highest at Stns 14 and 15 within the cyclonic flow in the western 
a
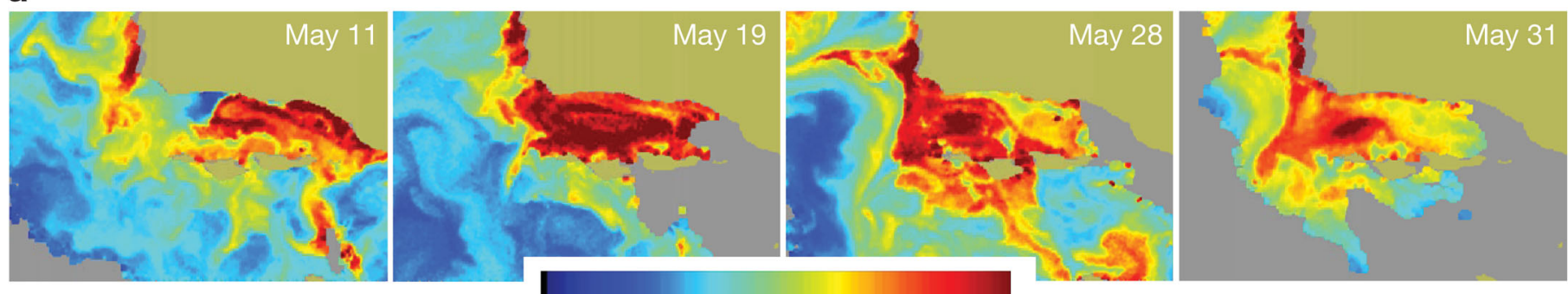

b

$0.10 \quad 1.00 \quad 10.00 \mathrm{mg} \mathrm{m}^{-1}$
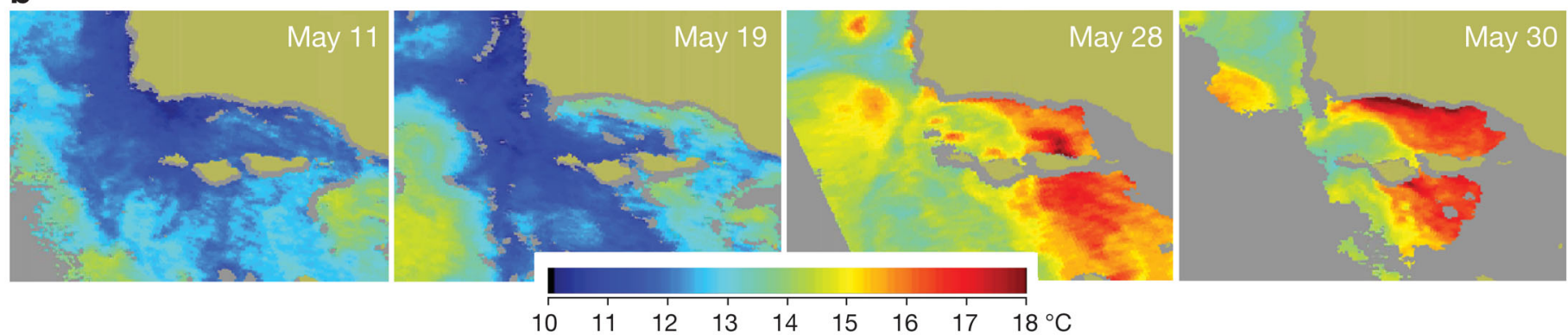

$\begin{array}{lllllllll}10 & 11 & 12 & 13 & 14 & 15 & 16 & 17 & 18^{\circ} \mathrm{C}\end{array}$
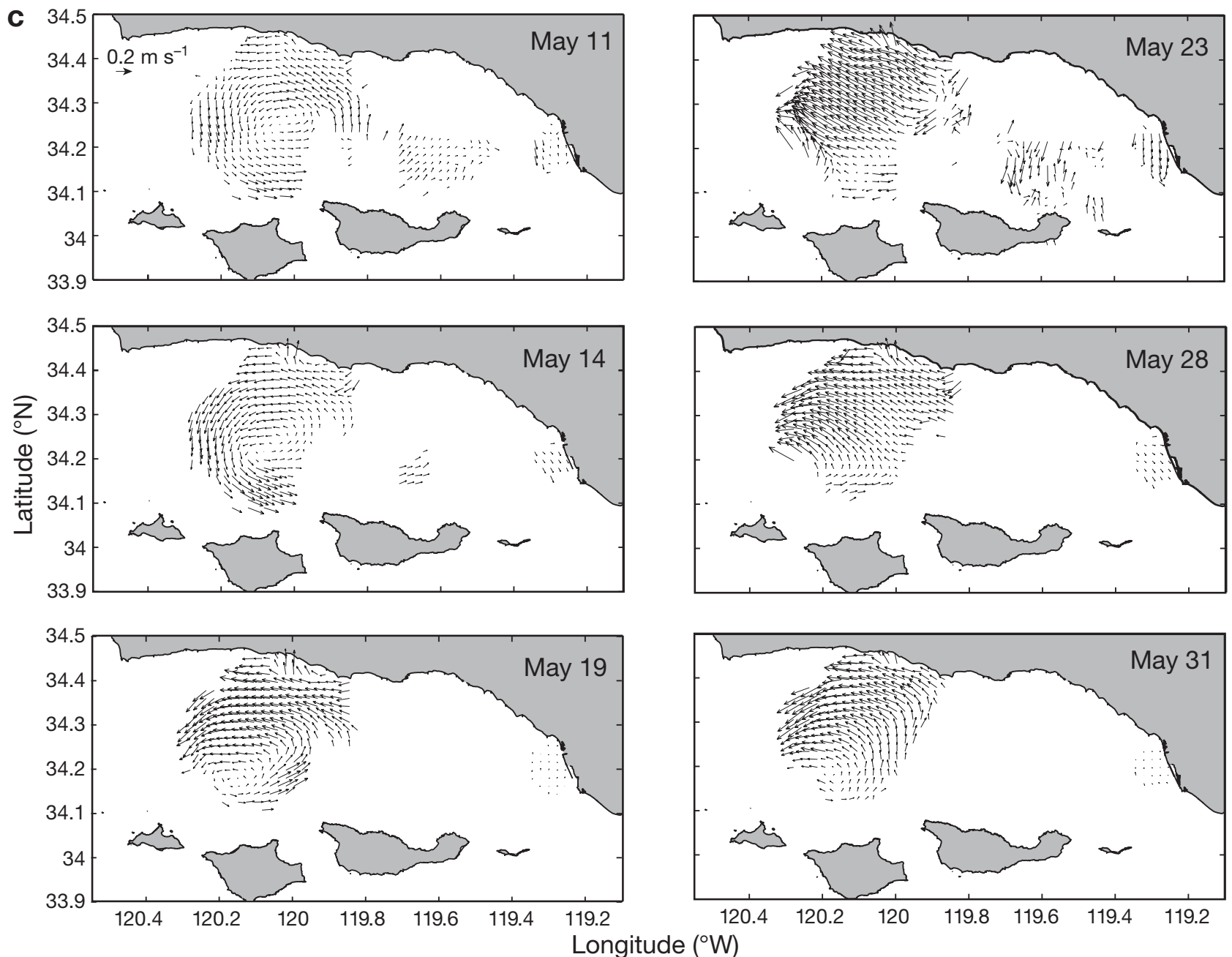

Fig. 3. Time series of (a) SeaWiFS images of chlorophyll concentration, (b) AVHRR SST imagery, and (c) 24 h means of surface current vectors from HF radar in May 2003. Dates were selected based on availability of high quality data from all sensor platforms 


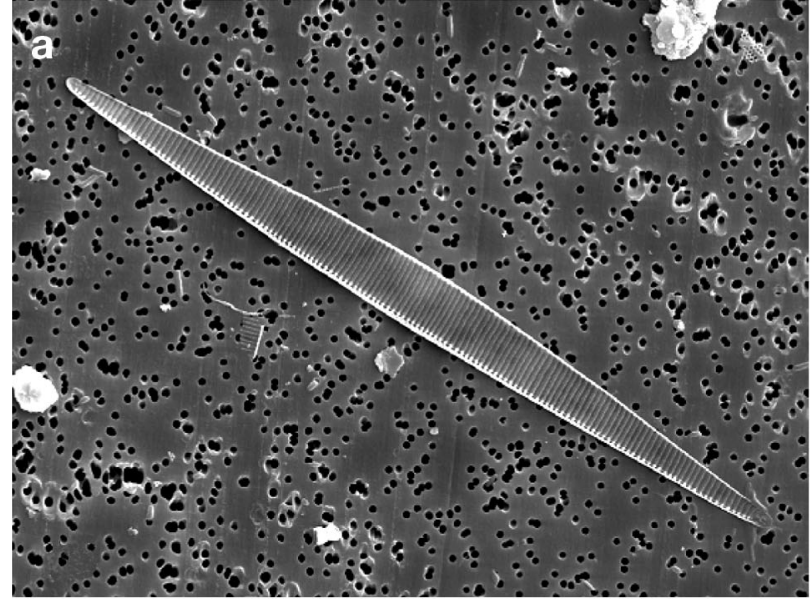

$20 \mu \mathrm{m}$ - -1-

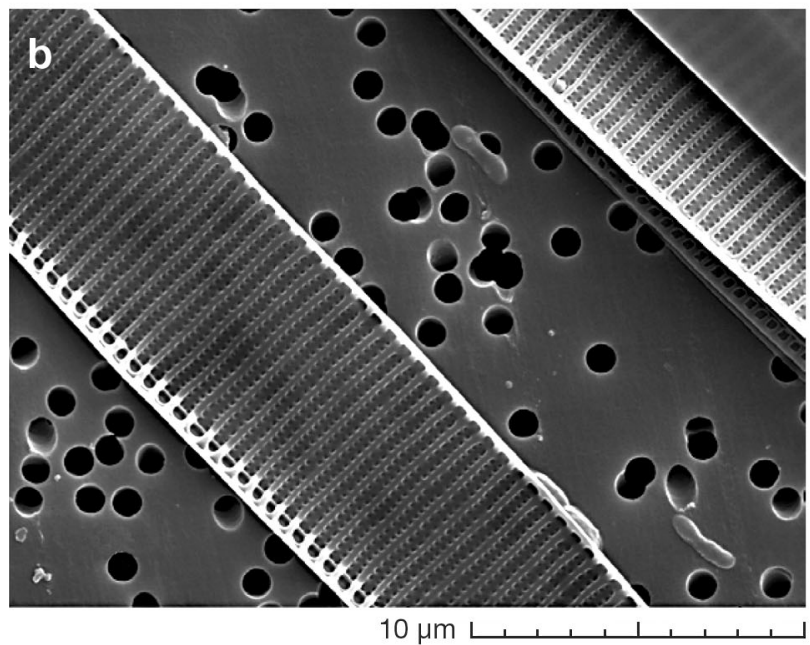

Fig. 4. Pseudo-nitzschia australis. SEM images from whole water samples. (a) Typical length of $\sim 100 \mu \mathrm{m}$ for a single frustule and (b) characteristic 2 rows of poroids per striae

channel (data not shown). Scanning electron microscopy of samples from 7 stations revealed Pseudonitzschia australis Frenguelli (Hasle 1978) (Fig. 4) to be the only Pseudo-nitzschia species present. Dominance by $P$. australis within this bloom is corroborated by cell counts for samples taken from Goleta Pier located between Stns 14 and 20 by B. Prézelin (unpubl. data).

Pseudo-nitzschia australis cell abundance at $5 \mathrm{~m}$ was $>1 \times 10^{6}$ cells $^{-1}$ both along the mainland coast and in mid-channel (Fig. 5a). The highest levels of particulate DA concentration (1000 to $1684 \mathrm{ng} \mathrm{l}^{-1}$; hereafter pDA) were located near the center of the channel (Fig. 5b) coincident with the highest $P$. australis abundance $\left(\sim 2 \times 10^{6}\right.$ cells $\left.^{-1}\right)$ and the region of cyclonic flow (Fig. 3c). Cellular DA concentrations (hereafter cDA) ranged from 0.14 to $2.1 \mathrm{pg} \mathrm{cell}^{-1}$ (Fig. $5 \mathrm{c}$ ). P. australis cells with the highest cDA were located in the middle of the channel in the region of cyclonic flow (Fig. 3c) coincident with a local maximum cell abundance (Fig. 5a) and pDA (Fig. 5b).

Chlorophyll a concentration, primary productivity and carbon assimilation number $\left(P^{B}\right)$ at $5 \mathrm{~m}$ were elevated throughout the $\mathrm{SBC}$, with strong along-channel gradients (Fig. 6). The highest levels of $5 \mathrm{~m}$ chlorophyll a (30 to $35 \mathrm{mg} \mathrm{m}^{-3}$; Fig. 6a) were observed in the central to western channel, while maxima for depthintegrated chlorophyll a (591 to $683 \mathrm{mg} \mathrm{m}^{-2}$; Fig. 6b) were observed at central nearshore stations. This pattern was again observed for $5 \mathrm{~m}$ rates of primary production (max. $=1198 \mathrm{mg} \mathrm{C} \mathrm{m}{ }^{-3} \mathrm{~d}^{-1}$; Fig. 6c), which were highest over the center of the SB Basin within the
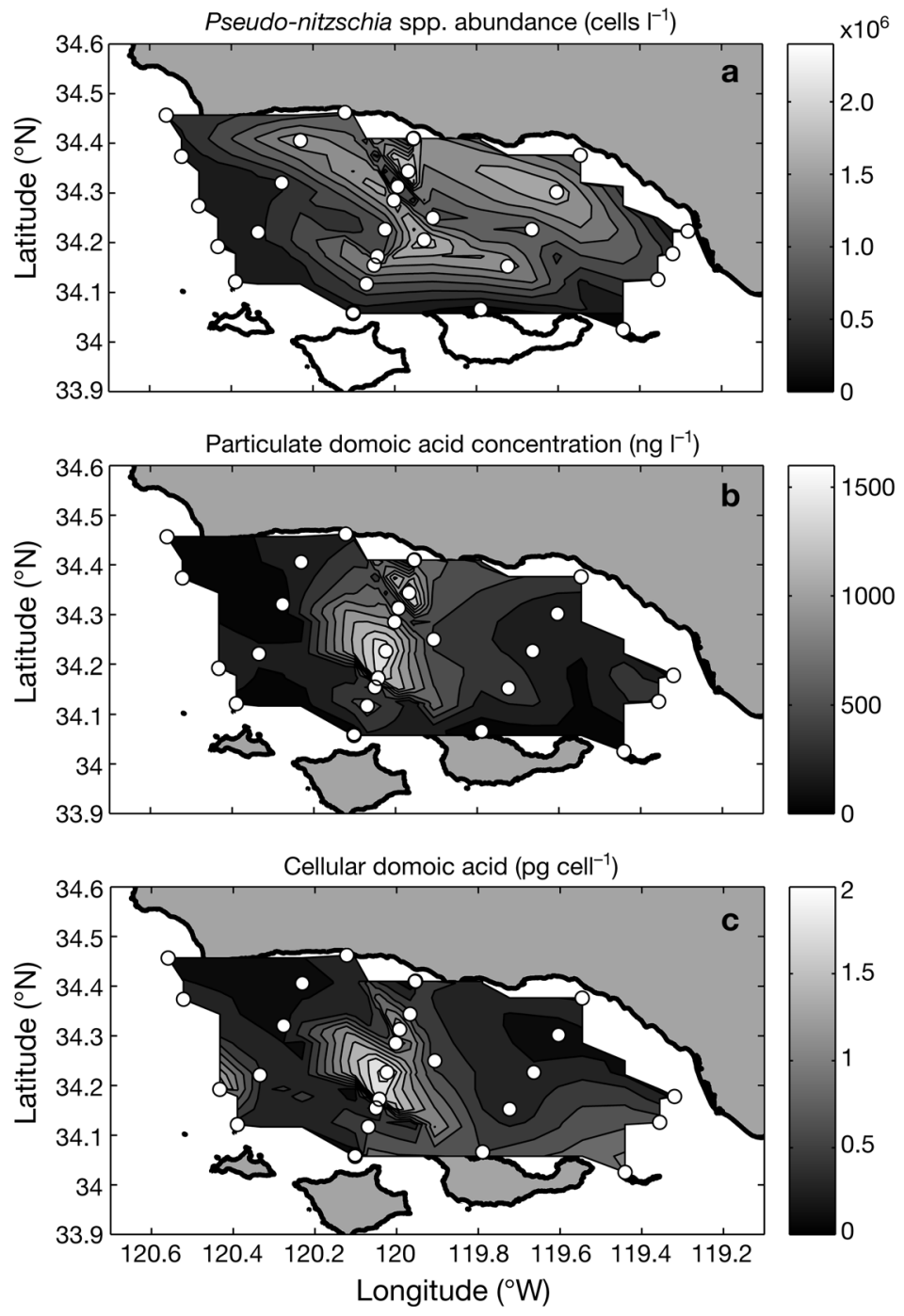

Fig. 5. Channel-wide measurements of (a) Pseudo-nitzschia australis cell abundance $(\mathrm{n}=31)$, (b) particulate domoic acid, $(\mathrm{DA}, \mathrm{n}=31)$ and (c) cellular DA $(\mathrm{n}=28)$, all at $5 \mathrm{~m}$ depth. O: sampling locations along CTD grid and 7-station harmful algal bloom transect. No cell abundance and DA data are available for grid Stns 22 and 3, respectively, because of sample loss 

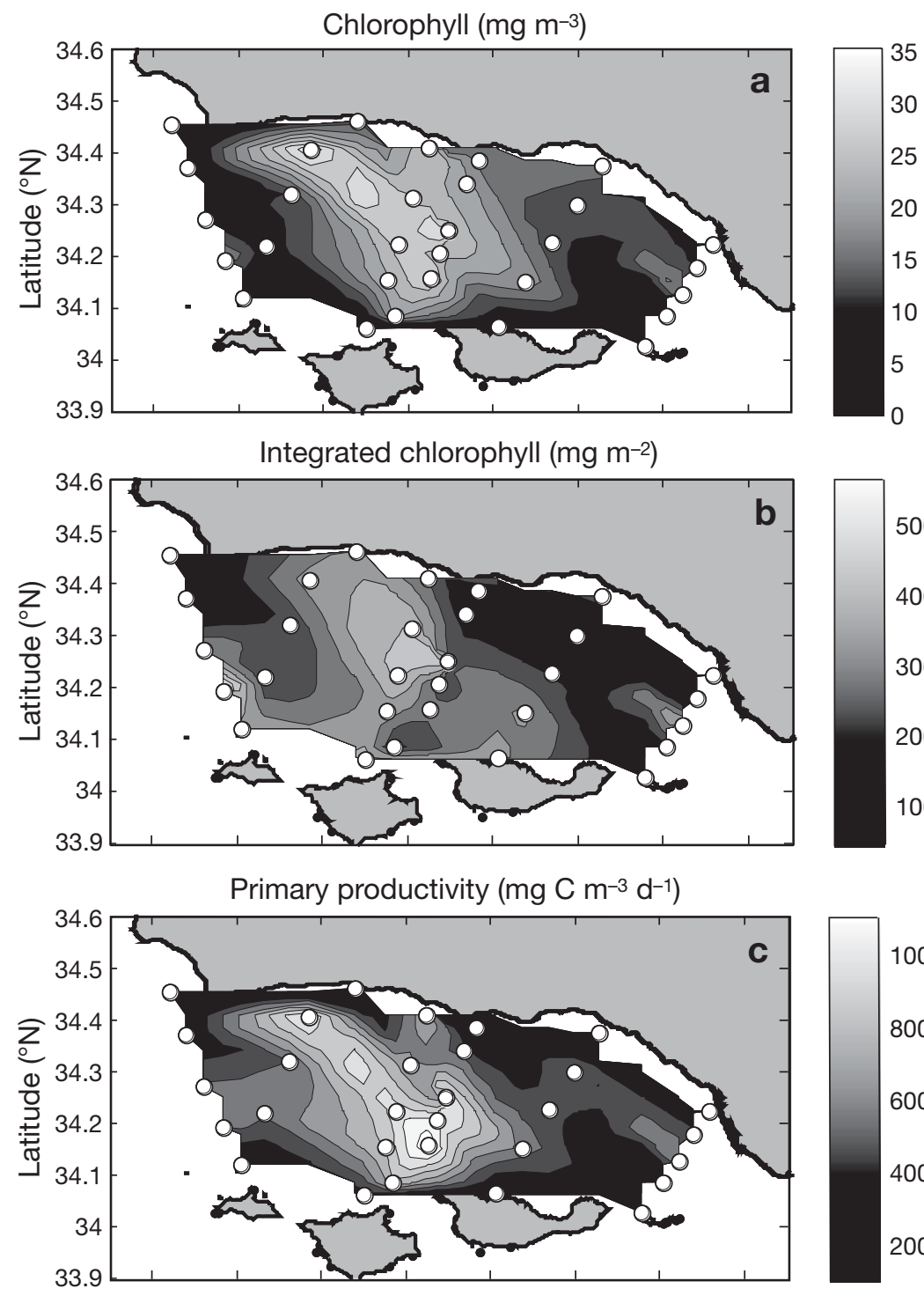

Carbon assimilation number $\left(\mathrm{mg} \mathrm{C} \cdot \mathrm{mg} \mathrm{chl}^{-1} \mathrm{~m}^{-3} \mathrm{~d}^{-1}\right)$
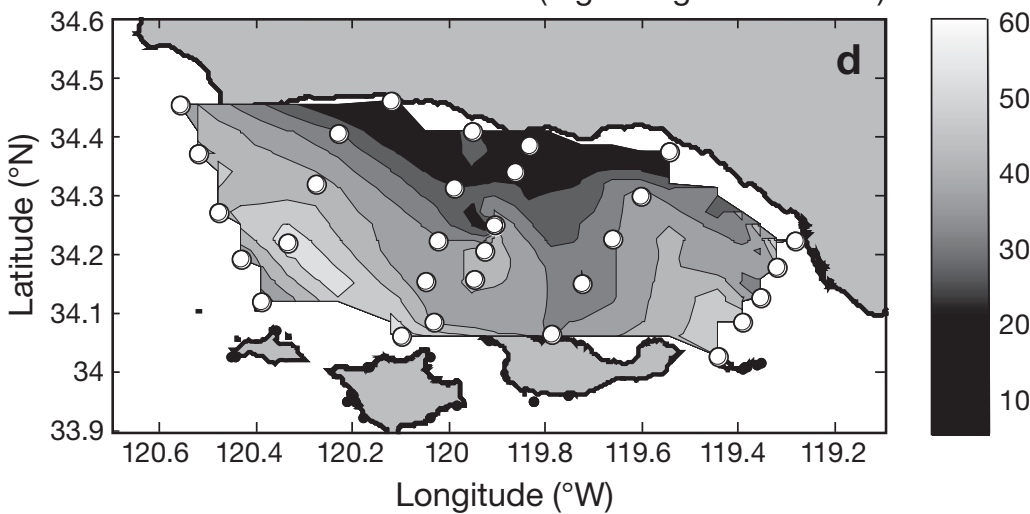

50

40

30

20

10

Fig. 6. In situ biomass measurements. (a) Chlorophyll a $(\mathrm{n}=38)$, (b) integrated chlorophyll $a(n=31)$, (c) primary production rate $(\mathrm{n}=31)$ and (d) carbon assimilation number, $P^{B}(\mathrm{n}=31)$ at $5 \mathrm{~m}$. (O) in (a) and (b): sampling stations along CTD grid, Plumes and Blooms (PnB) and harmful algal bloom transects; $(\bigcirc)$ in $(c)$ and $(d)$ : productivity measurements for CTD and PnB transects only region of cyclonic flow. Depth-integrated primary productivity (data not shown) for the $7 \mathrm{PnB}$ stations were highest in the central channel and ranged from 7427 to $8485 \mathrm{mg} \mathrm{C} \mathrm{m}^{-2} \mathrm{~d}^{-1}$ which, relative to the spring average of $2588 \mathrm{mg} \mathrm{C} \mathrm{m}{ }^{-2} \mathrm{~d}^{-1}$ (M. Brzezinski SBC-LTER unpubl. data), demonstrates the significant magnitude of phytoplankton productivity during the bloom. $P^{B}$ was highest $\left(\sim 67 \mathrm{mg} \mathrm{C} \mathrm{mg}^{-1} \mathrm{Chl}\right.$ $\left.\mathrm{d}^{-1}\right)$ at Stn 6 in the western channel, and moderate at mid-channel stations (Fig. 6d).

The cyclonic flow that coincided with the central area of dense biomass and DA accumulation became at times a coherent eddy that translated westward from 11 to 23 May, after which time the center of the eddy was west of the radar coverage area. Mean sur300 face velocity vectors for 16 to 21 May show a cyclonic turning (Fig. 7a) typical of the eddy circulation that often appears in the SBC, usually in spring and summer (Harms \& Winant 1998, Oey et al. 2001, Winant et al. 2003). The surface circulation was centered north of Santa Rosa Island at $34.2^{\circ} \mathrm{N}$ and $120.1^{\circ} \mathrm{W}$ (Fig. 7a). Unfortunately, HF radar 000 coverage during May 2003 was insufficient to allow full resolution of the spatial structure of the circulation. A vertical cross-section from the Scanfish tow through the eddy on 19 May shows its extensive subsurface manifestation (Fig. 7b). Upward doming of isopycnals is clearly evident along the transect (Fig. 7b) and is consistent with cyclonic circulation.

In situ relative fluorescence measured through the eddy with the Scanfish profiler on 19 May shows maximum phytoplankton biomass in the center of the eddy, positioned between $34.1^{\circ} \mathrm{N}$ and $34.4^{\circ} \mathrm{N}$ and penetrating to $\sim 15 \mathrm{~m}$ (Fig. 7b), coincident with the $1 \%$ light depth range at all stations. The eddy center also coincided with high levels of chlorophyll a, primary productivity (Fig. 6), Pseudo-nitzschia australis abundance, ambient pDA, and cDA levels (Fig. 5). By 22 May, a resampling of the same transect line indicated a substantial decrease in fluorescence where the high chlorophyll a patch had previously been, as well as apparent northward movement of that patch as nearsurface isopycnals flattened (Fig. 7b). The high chlorophyll a concentrations in the eddy center are also evident in satellite ocean color imagery days after the study pe- 
a

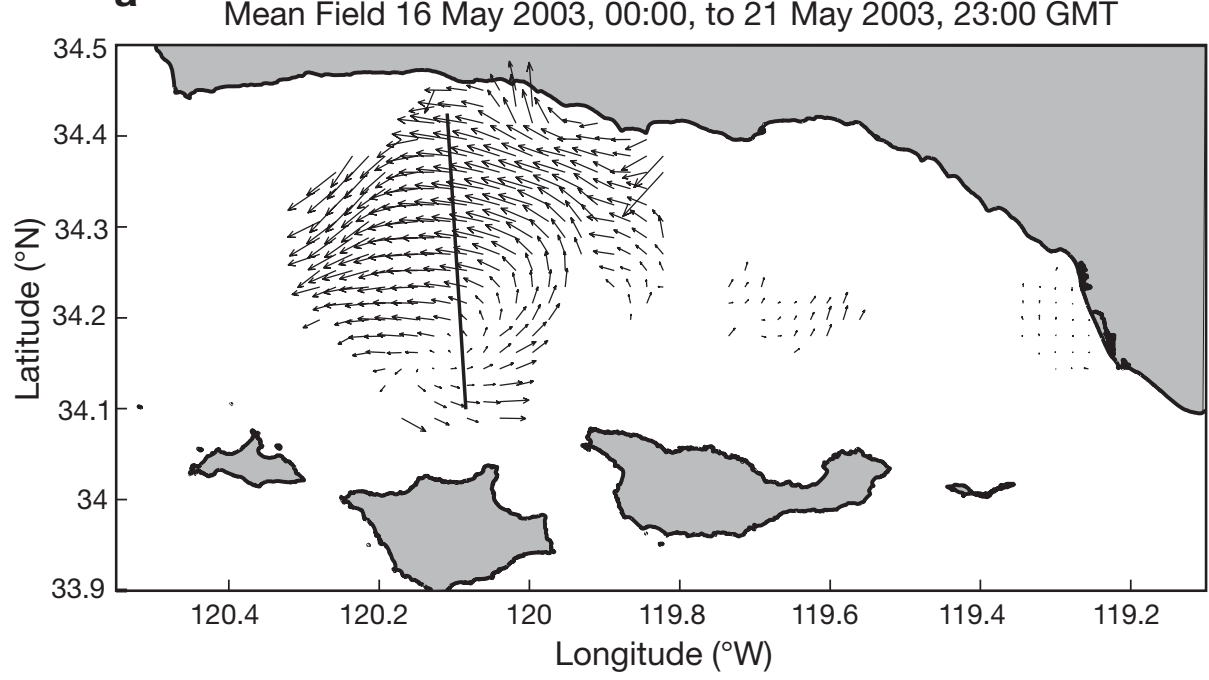

Fig. 7. (a) HF radar image of mean surface currents for period 16 to 21 May 2003, showing cyclonic eddy during cruise period; vertical line shows mid-channel, Scanfish profiler transect which provided (b) north-south vertical cross-sections of potential density and relative fluorescence on 19 (top panels) and 22 (bottom panels) May b
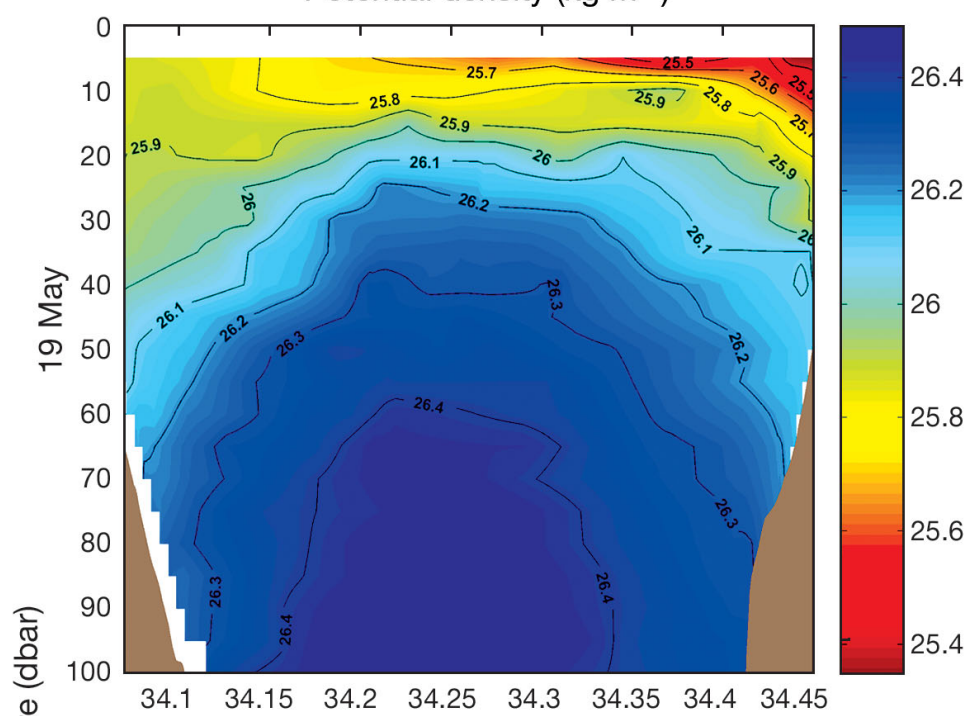

25.4

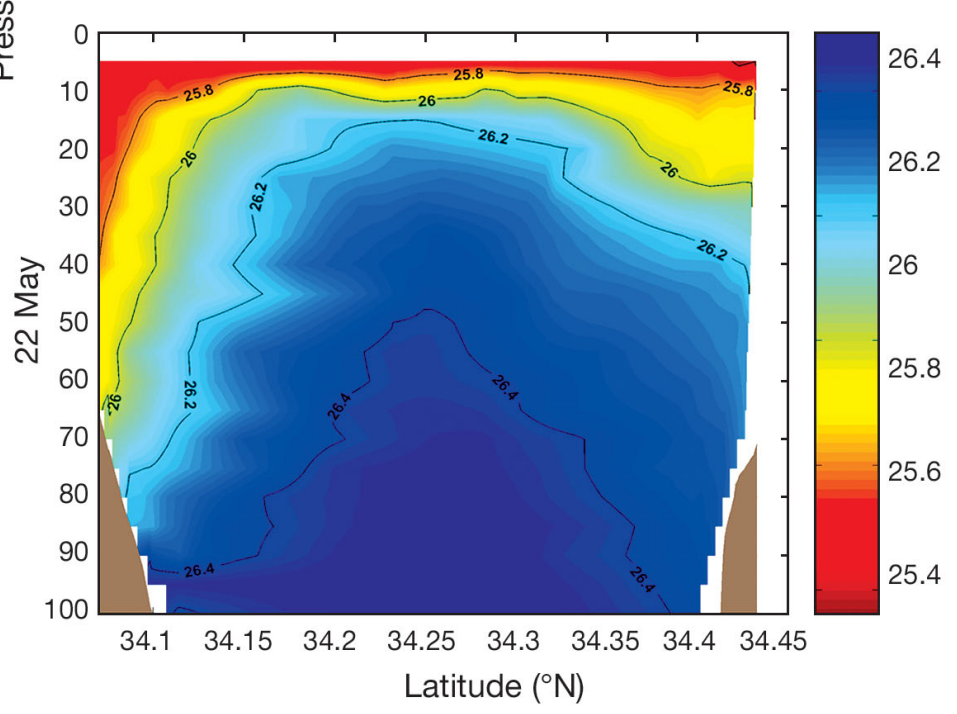

Relative fluorescence
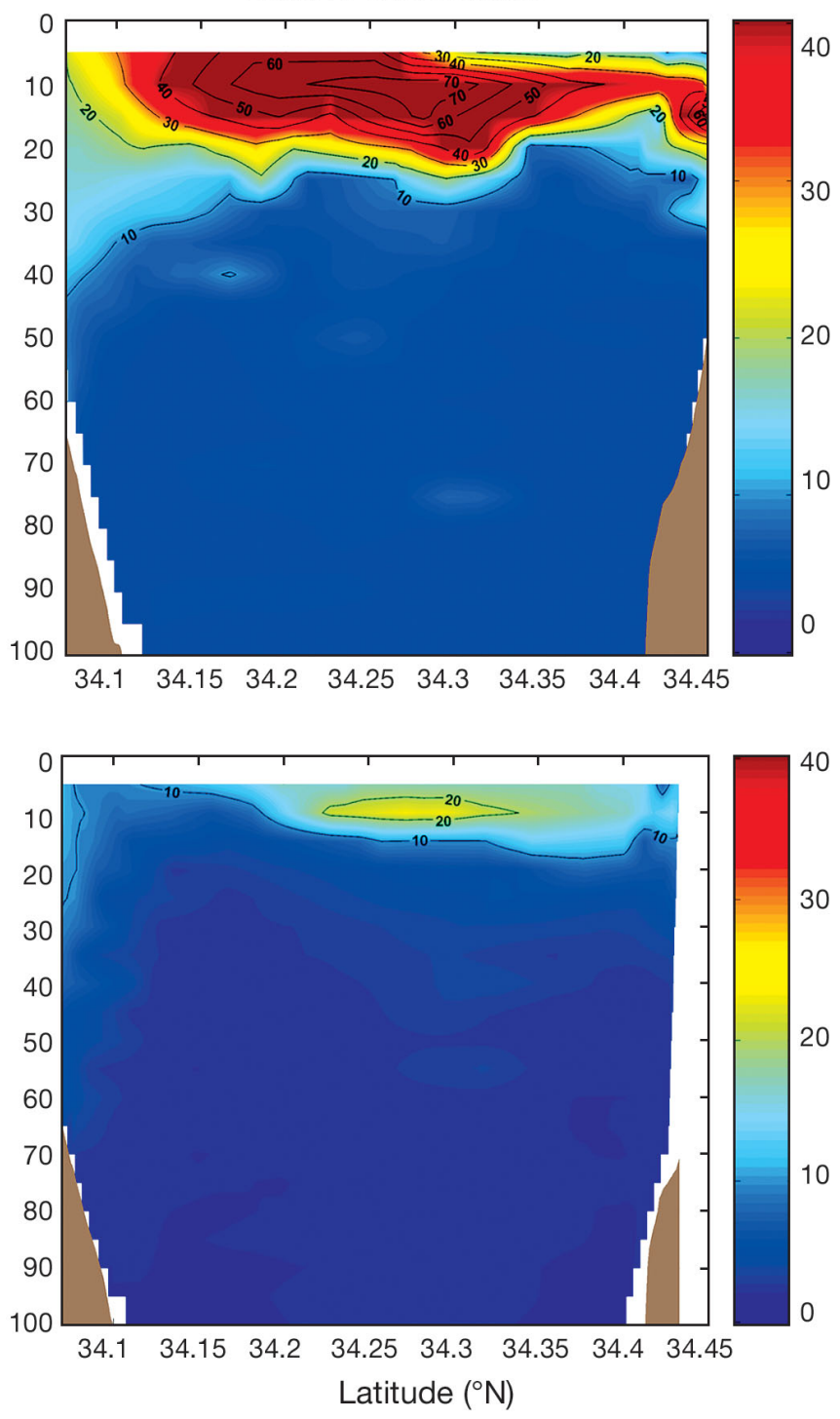
riod. For example, the 28 May SeaWiFS image (Fig. 3a) shows that the high-biomass patch shifted further west between Point Conception and San Miguel Island, suggestive of the westward trajectory often seen with cyclonic circulation in the SBC (Harms \& Winant 1998, Beckenbach 2004).

Nutrient concentrations measured at $5 \mathrm{~m}$ along the channel-wide grid are consistent with upwelling in or near the west channel and advection of warmer, lownutrient waters along the mainland coast from the east channel (Fig. 8). Nitrate ranged from 0.1 to $17.9 \mu \mathrm{M}$ (Fig. 8b), silicic acid from 0.1 to $21 \mu \mathrm{M}$ (Fig. 8c), and orthophosphate from 0.8 to $1.4 \mu \mathrm{M}$ (not shown) at $5 \mathrm{~m}$,
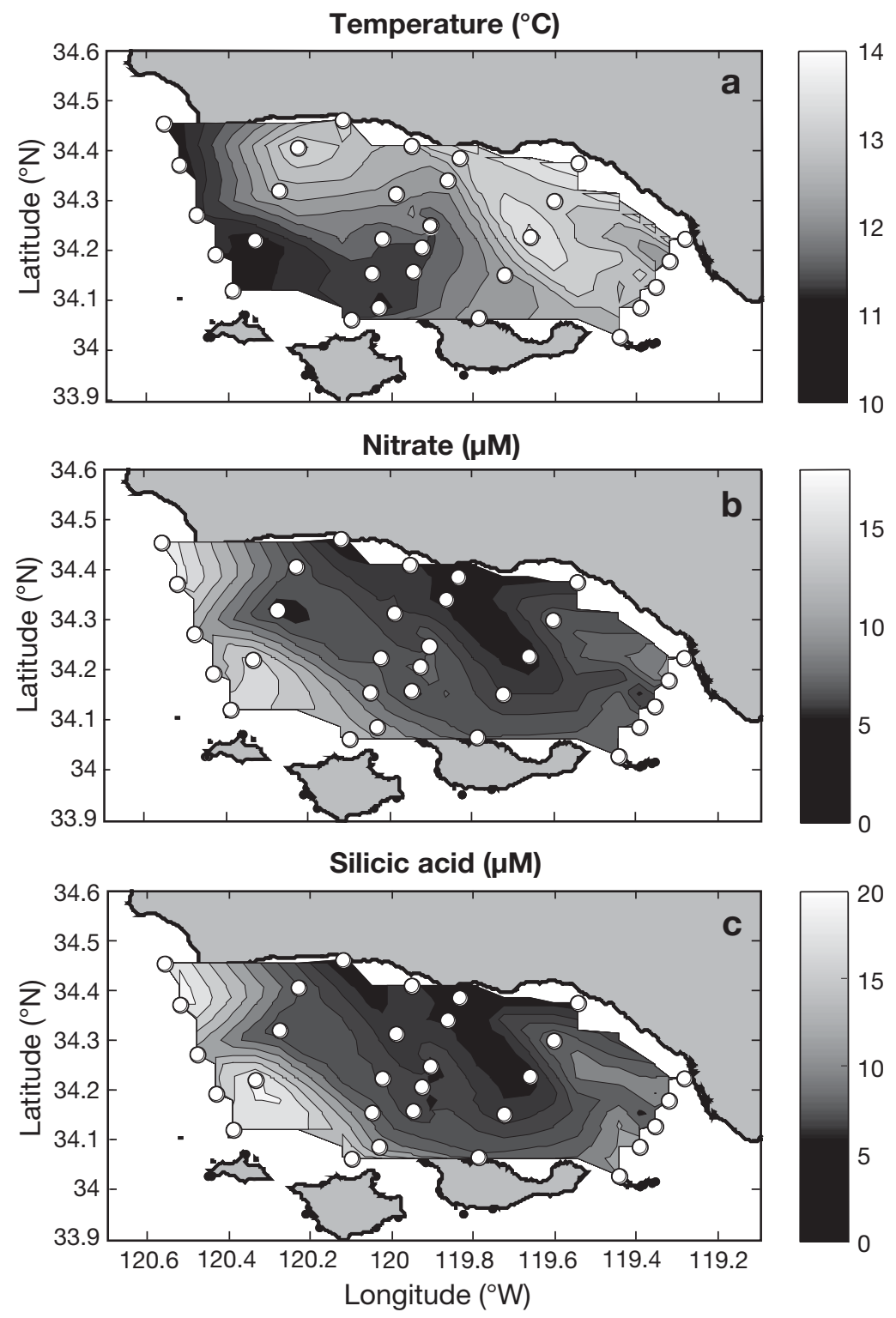

Fig. 8. (a) Temperature, (b) nitrate and (c) silicic acid concentrations at $5 \mathrm{~m}$ along LTER grid, 'Plume and Bloom' and harmful algal bloom transects. $\bigcirc$ : sampling stations $(n=34)$ with the maximum concentration for each nutrient located in the west channel probably associated with waters originally upwelled off Point Conception. For all inorganic nutrients, concentrations measured at $5 \mathrm{~m}$ were not significantly different from those at the surface. Nutrient input from land is assumed negligible because rainfall for the major watersheds in the Santa Barbara coastal region was generally low in May 2003 and averaged $5.7 \mathrm{~cm}$ for the entire Carpenteria Valley (Fig. 1) on 2 May, our last rain record before data collection (T. Robinson SBC-LTER, pers. comm.).

Pseudo-nitzschia australis abundance and pDA at $5 \mathrm{~m}$ were significantly and positively correlated with each other, while both were negatively correlated with silicic acid, nitrate and orthophosphate concentrations (Table 1). However, a significant negative correlation between $\mathrm{pDA}$ and the ratios of $\mathrm{Si}(\mathrm{OH})_{4}: \mathrm{NO}_{3}{ }^{-}$ and $\mathrm{Si}(\mathrm{OH})_{4}: \mathrm{PO}_{4}{ }^{3-}$ at $5 \mathrm{~m}$ (Table 1) suggests a possible relationship with $\mathrm{Si}$ limitation. This is also suggested by the nearly significant relationship between the abundance of toxigenic cells and the $\mathrm{Si}(\mathrm{OH})_{4}: \mathrm{NO}_{3}{ }^{-}$ and $\mathrm{Si}(\mathrm{OH})_{4}: \mathrm{PO}_{4}{ }^{3-}$ at $5 \mathrm{~m}(\mathrm{n}=28$ for each, Table 1).

Cellular DA levels exhibited an inconsistent relationship with nutrient concentrations. In the west channel, high cDA was associated with high concentrations of all nutrients and high $\mathrm{Si}(\mathrm{OH})_{4}: \mathrm{PO}_{4}{ }^{3-}$ ratios (Fig. 9a), while in the central channel it was associated with the lowest nutrient concentrations. This inconsistent relationship drives the poor linear correlation between cDA and all nutrient parameters (Table 1). We do note, however, that the highest cDA during the bloom corresponded with the lowest $\mathrm{Si}(\mathrm{OH})_{4}$ concentrations and was located in the center of the eddy.

\section{DISCUSSION}

We observed a strong local maximum in cellular DA ( 2.1 pg cell ${ }^{-1}$; Fig. 5c) coincident with the center of a cyclonic eddy in the SBC (Fig. 7). Bloom levels of Pseudonitzschia australis, producer of the highest cellular levels of DA for this genus (Garrison 1981, Buck et al. 1992, Bates 2000), accompanied high particulate pDA in the middle of the channel within a cyclonic eddy. This cyclonic flow in the SBC is driven by an east-west gradient in wind stress along the channel caused by an eastward reduction in 
Table 1. Spatial correlation coefficients (r) for selected biological, chemical, and physical variables at $5 \mathrm{~m}$. Values in bold are significant at $\alpha=0.05$. PP: primary productivity; P. cell abund: Pseudo-nitzschia australis abundance; pDA: particulate domoic acid; cDA: cellular domoic acid; $P^{B}$ : carbon assimilation number

\begin{tabular}{|c|c|c|c|c|c|c|c|c|c|c|c|c|}
\hline $\mathrm{r}$ & Chl a & PP & $\begin{array}{c}P \text { cell } \\
\text { abund. }\end{array}$ & $\mathrm{pDA}$ & cDA & $\mathrm{Si}(\mathrm{OH})_{4}$ & $\mathrm{PO}_{4}{ }^{3-}$ & $\mathrm{NO}_{3}^{-}$ & $T$ & $\mathrm{Si}(\mathrm{OH})_{4}: \mathrm{NO}_{3}{ }^{-}$ & $\mathrm{Si}(\mathrm{OH})_{4}: \mathrm{PO}_{4}{ }^{3-}$ & $P^{B}$ \\
\hline Chl a & - & 0.81 & 0.64 & 0.71 & 0.32 & -0.56 & -0.34 & -0.47 & 0.15 & -0.40 & -0.55 & -0.62 \\
\hline PP & & - & 0.53 & 0.43 & -0.01 & -0.17 & -0.05 & -0.18 & -0.08 & 0.19 & -0.04 & -0.24 \\
\hline$P$. cell abund. & & & - & 0.51 & -0.26 & -0.42 & -0.32 & -0.36 & 0.22 & -0.31 & -0.37 & -0.46 \\
\hline $\mathrm{pDA}$ & & & & - & 0.57 & -0.55 & -0.37 & -0.45 & -0.02 & -0.48 & -0.61 & -0.62 \\
\hline cDA & & & & & - & -0.19 & -0.10 & -0.18 & -0.57 & -0.20 & -0.23 & -0.03 \\
\hline $\mathrm{Si}$ & & & & & & - & 0.92 & 0.96 & -0.60 & 0.48 & 0.86 & 0.64 \\
\hline $\mathrm{P}$ & & & & & & & - & 0.98 & -0.74 & 0.26 & 0.69 & 0.55 \\
\hline $\mathrm{N}$ & & & & & & & & - & -0.71 & 0.26 & 0.73 & 0.59 \\
\hline$T$ & & & & & & & & & - & 0.05 & -0.33 & -0.14 \\
\hline $\mathrm{Si}: \mathrm{N}$ & & & & & & & & & & - & 0.74 & 0.37 \\
\hline $\begin{array}{l}\mathrm{Si}: \mathrm{P} \\
P^{B}\end{array}$ & & & & & & & & & & & - & 0.68 \\
\hline
\end{tabular}

the strength of (often intense) westerly winds (Oey et al. 2001, Beckenbach 2004). It appears from SeaWiFS chlorophyll $a$, AVHRR SST and HF radar data (Fig. 3) that in midMay 2003 there was a shift in synoptic states from upwelling along the mainland coast to cyclonic flow (which generally requires a change in the magnitude of this wind stress gradient; Beckenbach 2004). Upwellingfavorable wind velocities did diminish from 11 to 15 May, just prior to the sampling cruise (Fig. 2), which might have been sufficient for the development of mesoscale, cyclonic flow.

The high pDA and cDA near the eddy center (Fig. 5b,c) is consistent with the retention capabilities associated with the convergent centers of cyclones (and alternating anticyclones) that propagate over the SBC (Nishimoto \& Washburn 2002; Beckenbach 2004, Beckenbach \& Washburn 2004). While upwelling was occurring within the SBC during our study, the contiguity of cold, high-nutrient water in the southwestern SBC and water offshore (Fig. 8a) suggests that the bloom was also influenced by water that had upwelled outside the SBC and had been advected into the channel. We speculate that both these nutrient sources supported the bloom throughout our observations during the transition to convergent flow within the SBC. The net result was the development of a toxigenic Pseudonitzschia australis bloom, with the most toxic cells concentrated in the convergent center of the eddy (Fig. 5).

It is difficult to separate the effects of eddy retention from other factors that may influence Pseudo-nitzchia spp. growth rates and DA production. Outside the

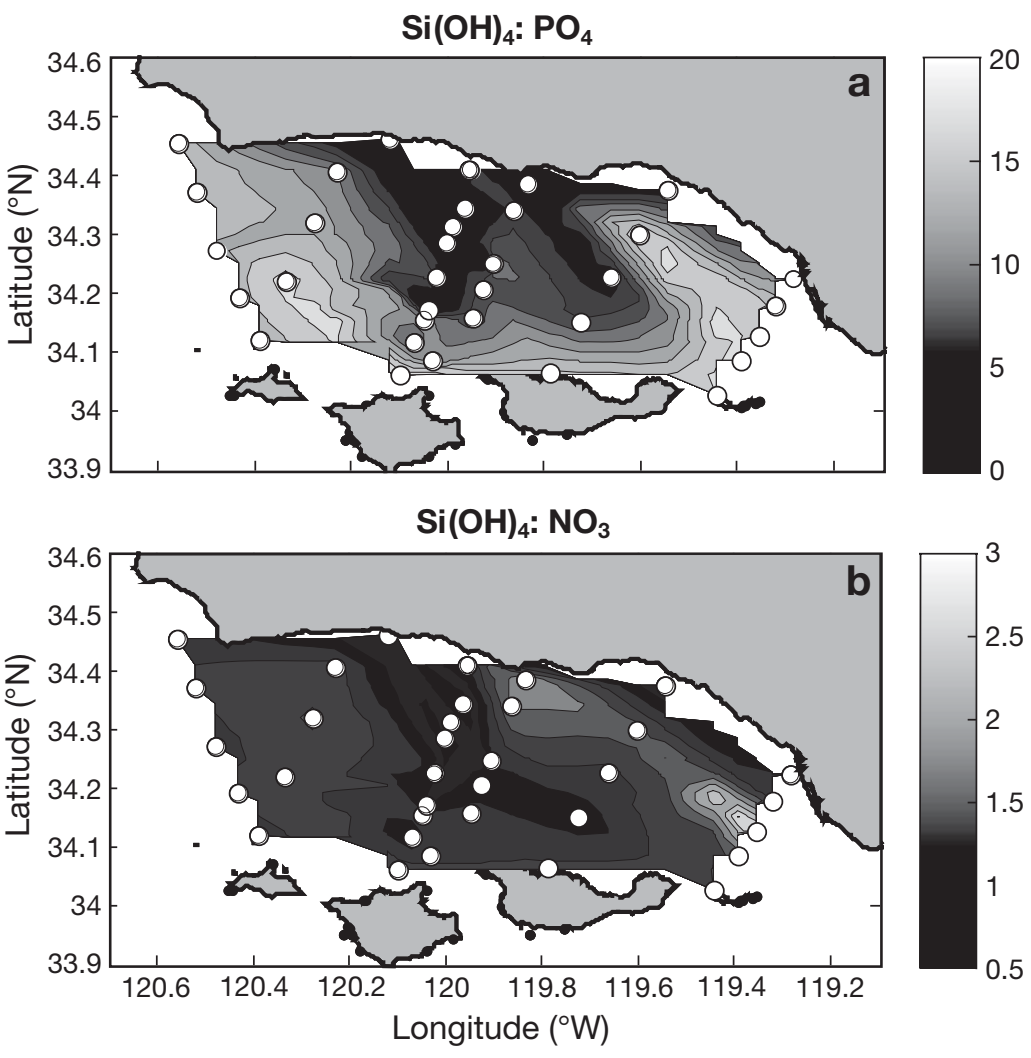

Fig. 9. Comparison of (a) silicic acid: phosphate ratio and (b) silicic acid: nitrate ratios at $5 \mathrm{~m}$. O: sampling points along CTD grid, Plume and Bloom and harmful algal bloom transects $(n=37)$

eddy, we observed high $P$. australis abundance, but only moderate levels of pDA, a factor that underscores the difficulty in predicting DA levels from Pseudonitzschia spp. cell abundance in natural blooms. Such inferences are further complicated by genetics. Orsini et al. (2004) found high variability in rDNA internal 
transcribed spacer-types among members of the nontoxic species $P$. delicatissima. Such 'cryptic diversity' may lead to toxigenic and non-toxigenic strains coexisting within an apparently monospecific bloom of Pseudo-nitzschia. High clonal variability in DA production has been demonstrated for P. australis and P. multiseries from Monterey Bay, California (Kudela et al. 2003b). However, Evans et al. (2005) also showed high clonal diversity, but with low genetic differentiation, within P. pungens assemblages in the more physically mixed environment of the North Sea. Clone-level diversity may have influenced the spatial patterns of cell abundance and toxicity that we observed in the SBC (Fig. 5b,c).

DA levels and rates of primary production were highest in the center of the eddy, but the $P^{B}$ maximum was offset to the west of the eddy, suggesting that the high primary productivity within the eddy may have been the result of a large accumulation of biomass under suboptimal growth conditions that may have also contributed to the higher toxicity of those cells. This supports the hypothesis that long residence times of Pseudo-nitzschia spp. cells in the euphotic zone under low nutrient conditions promote DA production (Marchetti et al. 2004).

\section{Chemical drivers of toxigenic bloom formation}

In coastal upwelling systems, diatom growth is often stimulated by the vertical injection of inorganic nutrients and is further controlled by the rate of nutrient drawdown during a given upwelling cycle (Wilkerson \& Dugdale 1987, Zimmerman et al. 1987). Si limitation retards the ability of diatoms to outcompete other phytoplankton once silicic acid levels fall below ca. $2 \mu \mathrm{M}$ (Egge \& Aksnes 1992) and ratios of silicic acid to dissolved inorganic nitrogen are less than the Redfield/Brzezinski value of 1:1 (Brzezinski 1985, Turner et al. 1998). There is evidence, however, that the genus Pseudo-nitzschia has a lower $\mathrm{Si}$ requirement than many other diatoms (Marchetti et al. 2004) and consequently can maintain biomass in the euphotic zone in the later successional stages of a spring bloom (see Bates et al. 1998). Kudela et al. (2003a) found that Pseudo-nitzschia spp. blooms off California occur during the transitional stages from a strong upwelling/ high nutrient regime to a weak upwelling/low nutrient regime. Our cruise occurred during such a transitional period from an upwelling mode to a cyclonic mode.

The significant negative correlations observed between silicic acid concentration, $\mathrm{Si}(\mathrm{OH})_{4}: \mathrm{NO}_{3}{ }^{-}$and $\mathrm{Si}(\mathrm{OH})_{4}: \mathrm{PO}_{4}{ }^{3-}$ ratios and Pseudo-nitzschia australis abundance (Table 1) supports the hypothesis that Pseudo-nitzschia spp. populations are able to drive sili- cic acid concentrations to low levels relative to those of nitrate and orthophosphate while remaining viable and dominant in the phytoplankton. If the retention time of cells in surface waters were prolonged by convergence within the eddy, then continued drawdown of nutrients, and in particular silicic acid, may have enhanced DA production there. Indeed, silicic acid concentrations were lowest in the eddy center, where $5 \mathrm{~m}$ cDA was highest (Figs. 5c \& 8c). While we are unable to assess nutrient limitation directly with our data set, we note that $P$. australis abundance was highest in waters with the lowest $\mathrm{Si}(\mathrm{OH})_{4}: \mathrm{PO}_{4}{ }^{3-}$ and $\mathrm{Si}(\mathrm{OH})_{4}: \mathrm{NO}_{3}{ }^{-}$ (Table 1, Fig. 9) supporting a link between a low-Si regime and $P$. australis growth. In continuous culture, Si stress induces $P$. multiseries to take up less $\mathrm{Si}(\mathrm{OH})_{4}$ relative to $\mathrm{NO}_{3}{ }^{-}$, lowering cellular $\mathrm{Si}(\mathrm{OH})_{4}: \mathrm{NO}_{3}{ }^{-}$ratios from $\sim 2$ under nutrient-replete conditions to an average of $\sim 0.68$ under conditions of Si limitation (Pan et al. 1996b). Ambient $\mathrm{Si}(\mathrm{OH})_{4}: \mathrm{NO}_{3}{ }^{-}$ratios in the central patch of high biomass within the eddy (Fig. 6a) that coincided with highest pDA and cDA (Fig. 5b,c) did fall where $\mathrm{Si}(\mathrm{OH})_{4}: \mathrm{NO}_{3}{ }^{-} \sim 0.6$ (Fig. 9b), but were not exclusive to that region. Conversely, over much of the channel where silicic acid concentrations were significantly higher (5 to $20 \mu \mathrm{M}$; Fig. $8 \mathrm{c}$ ), the $\mathrm{Si}(\mathrm{OH})_{4}: \mathrm{NO}_{3}{ }^{-}$ratios were at Redfield or higher (Fig. 9b) and pDA and cDA levels were consistently low. The association between decreasing $\mathrm{Si}(\mathrm{OH})_{4}: \mathrm{NO}_{3}{ }^{-}$values and rising DA levels has also been observed in Monterey Bay (R. Kudela unpubl. data). Combining their results with ours suggests that DA production by $P$. australis is likely when the $\mathrm{Si}(\mathrm{OH})_{4}: \mathrm{NO}_{3}{ }^{-}$is $<2$.

Enhanced DA production occurs in stationary phase cells (Pan et al. 1996a,b, 1998, Bates et al. 1998, Kudela et al. 2003b) when carbon assimilation has significantly decreased and cells are no longer in their physiological prime. In the absence of direct micro- and macronutrient limitation assays, we examined the $P^{B}$ data set for indications of physiological stress. Phytoplankton biomass, pDA and cDA were all highest in areas with generally low $P^{B}$ (Fig. 6d). Our in situ $P^{B}$ values (Fig. 6d) are in agreement with values obtained for Pseudonitzschia multiseries from culture which show mean carbon assimilation rates of $18 \mu \mathrm{g} \cdot \mu \mathrm{g} \mathrm{chl} \mathrm{Ch}^{-1} \mathrm{~d}^{-1}$ for Silimited cultures compared to values of $38 \mu \mathrm{g} \cdot \mu \mathrm{g} \mathrm{chl}{ }^{-1}$ $\mathrm{d}^{-1}$ for the same species under nutrient-replete conditions (Pan et al. 1996b). In our field data, $P^{B}$ showed an expected strong positive correlation with all macronutrients. There was a nearly significant negative correlation between primary productivity and $P^{B}$ (Table 1 , Fig. 6c,d) that could be interpreted as an indication that the most productive regions were those with high biomass that was fixing carbon at a relatively low chlorophyll a-specific rate compared to other areas. Taken together, the low $P^{B}$ and high primary produc- 
tivity observed in the center of the eddy indicate a phytoplankton population with poor cellular health, perhaps as a result of a long residence time in surface waters.

\section{Comparison with other Pseudo-nitzschia australis blooms on the west coast of North America}

In this study, SEM of filtered water samples revealed that Pseudo-nitzschia australis (Fig. 4) dominated the bloom we observed and that this species was the major DA producer (although other Pseudo-nitzschia species may have been present in very low numbers). In a review of Pseudo-nitzschia studies, Bates et al. (1998) reported that $P$. australis, $P$. multiseries and $P$. pseudodelicatissima all occur off the west coast of North America, although which species tend to dominate during toxic events in the Southern California Bight is unpredictable.

Prior to the recent blooms in the $\mathrm{SBC}$, toxigenic blooms were considered rare in the Southern California Bight, leading Lange et al. (1994) to hypothesize that conditions in this area were not appropriate for DA production or its accumulation. Temporal and spatial variability in the magnitude of DA events may have confounded detection efforts. For instance, the maximum pDA (1684 $\mathrm{ng} \mathrm{l}^{-1}$ ) recorded here in the $2003 \mathrm{SBC}$ event was about 4 times lower than maxima observed during another $P$. australis bloom in the SBC the following year (Mengelt 2006) or those recorded for $P$. australis at Point Conception during the 1998 bloom of $P$. australis along the entire California coast (max. $6300 \mathrm{ng} \mathrm{l}^{-1}$; Scholin et al. 2000, Trainer et al. 2000). It is also important to note that relative to the maximum concentrations of pDA found in Monterey Bay in 1998 (7500 ng l-1 ), 2003 SBC levels were quite low (Trainer et al. 2000). The cDA levels (0.14 to $2.1 \mathrm{pg} \mathrm{cell}^{-1}$ ) reported herein are also at the low end of the range $(0$ to $78 \mathrm{pg} \mathrm{cell}^{-1}$ ) reported by Scholin et al. (2000) and Trainer et al. (2000). Despite these relatively low DA levels observed in May 2003, however, toxin concentrations were sufficiently high to cause 500 sea lion and 50 common dolphin deaths in the region (Langlois 2004), underscoring the difficulty in predicting DArelated food web effects, and perhaps indicative of the role of residence time in determining their strength.

\section{CONCLUSIONS}

The channel-wide harmful bloom of Pseudo-nitzschia australis was probably prolonged and intensified by the entrainment of cells in a convergent, cyclonic eddy. While spatial variations in nutrient supply may have favored dominance by $P$. australis and the production of DA within the SBC, eddy circulation best explains the distribution of the most toxigenic cells. We do not know if the cells within the eddy were merely entrained or whether conditions within the eddy promoted toxin production; both are possible, and they are not mutually exclusive. Convergent mesoscale eddies in the SBC are common and often occur in spring when blooms of Pseudo-nitzschia spp. are most likely to occur. It is probable that phytoplankton routinely accumulate in these convergences and are then transported over significant distances as the eddies propagate westward. In the case of harmful algal blooms, this has significant implications for fisheries managers who rely on predictions of bloom distribution and transport to determine strategies for shellfish quarantines and alert systems.

Our data support the idea that Si stress plays a role in DA production, but the relationship between nutritional status and DA production appears complex, making it difficult to predict the magnitude and extent of DA poisoning from cell abundance and nutrient concentration. Species-level or possibly clone-level differences in growth and nutrient uptake and growth kinetics must be further explored before we can determine the utility of applying generic indices of nutrient stress to mixed-assemblage blooms. While our analysis has focused on macronutrients, DA production has also been linked to micronutrient supply (Ladizinsky \& Smith 2000, Rue \& Bruland 2001, Maldonado et al. 2002, Wells et al. 2005, B. Hopkinson \& K. Barbeau, Scripps Institution of Oceanography, pers. comm.). Current investigations into such trace metal controls on Pseudo-nitzschia spp. growth and DA production should contribute to developing predictive models based on physical and chemical drivers of toxicity.

Vertical nutrient delivery to surface waters during upwelling episodes is certainly a key factor in phytoplankton bloom initiation, but the transition from a mixed assemblage of diatoms to an assemblage dominated by Pseudo-nitzschia spp. appears more complicated and could be driven by assemblage-specific uptake rates of nutrients and interannual variability in seeding populations (Garrison 1981) that determine the appropriate conditions for toxigenic bloom development. In 2002 and 2003, DA levels were high enough to cause widespread sickness and death in the sea mammal population, but in 2004, bloom levels of $P$. australis and the highest $\mathrm{pDA}$ ever recorded for the SBC were not sufficiently prolonged to affect higher trophic levels (Mengelt 2006, B. Prézelin unpubl. data). Interestingly, mesoscale eddies have been observed during both the 2004 bloom and the most recent May/June 2005 bloom, during which sea lion strandings and mussel quarantines were coincident with only 
moderate levels of DA (Mengelt 2006) and Pseudonitzschia spp. $\left(\sim 10^{5}\right.$ cells $\left.^{-1}\right)$. We suspect that retention of phytoplankton induced by eddy circulation may play a role in the manifestation of marine mammal illness. It seems likely that continuing studies of the role of circulation on the horizontal movement of phytoplankton and their byproducts will better define what regulates the timing, intensity and persistence of these regional events.

Acknowledgements. This work is a product of the Santa Barbara Coastal Ecosystem LTER, funded by the US National Science Foundation (OCE 9982105). Support was also provided by a NASA Earth System Science graduate fellowship 06-ESSF-06R-12, and the NASA-funded Plumes and Blooms project headed by D. Siegel. Many thanks to the captain and crew of the UNOLS vessel RV 'Point Sur' (Moss Landing), B. Emery, J. Weaver, A. Alldredge, J. Jones, M. Armstrong, A. Roberts and T. Westberry. We are grateful to C. Mengelt and several anonymous reviewers for helpful insights that greatly improved this paper.

\section{LITERATURE CITED}

Adams NG, Lesoing M, Trainer VL (2000) Environmental conditions associated with domoic acid in razor clams on the Washington coast. J Shellfish Res 19:1007-1015

Allen WE (1922) Observations on surface distribution of marine diatoms between San Diego and Seattle. Ecology 3:140-145

Bates SS (2000) Domoic-acid-producing diatoms: another genus added! J Phycol 36:978-985

Bates SS, Garrison DL, Horner RA (1998) Bloom dynamics and physiology of domoic-acid-producing Pseudo-nitzschia species. In: Anderson DM, Cembella AD, Hallegraeff GM (eds) Physiological ecology of harmful algal blooms. Springer-Verlag, Heidelberg, p 267-292

Beckenbach E (2004) Surface circulation in the Santa Barbara Channel: an application of high frequency radar for descriptive physical oceanography in the coastal zone. $\mathrm{PhD}$ dissertation, University of California, Santa Barbara

Beckenbach E, Washburn L (2004) Low-frequency waves in the Santa Barbara Channel observed by high-frequency radar. J Geophys Res C109:C02010, doi:10.1029/ 2003JC001999

Bidigare RR, Van Heukelem L, Trees CC, Perl J (2003) HPLC phytoplankton pigments: sampling, laboratory methods, and quality assurance procedures. In: Mueller JL, Fargion GS, McClain CR (eds) Biogeochemical and bio-optical measurements and data analysis protocols, Vol 5. National Aeronautics and Space Administration, Washington, DC, p 5-14

Brzezinski MA (1985) The Si:C:N ratio of marine diatoms: interspecific variability and the effect of some environmental variables. J Phycol 21:347-357

Buck KR, Uttal-Cooke L, Pilskaln CH, Roelke DL, Villac MC, Fryxell GA, Cifuentes L, Chavez FP (1992) Autecology of the diatom Pseudonitzschia australis, a domoic acid producer, from Monterey Bay, California. Mar Ecol Prog Ser 84:293-302

Busse LB, Venrick EL, Antrobus R, Miller PE and 5 others (2006) Domoic acid in phytoplankton and fish in San Diego, CA, USA. Harmful Algae 5:91-101
Dortch Q, Robichaux R, Pool S, Milsted D and 6 others (1997) Abundance and vertical flux of Pseudo-nitzschia in the northern Gulf of Mexico. Mar Ecol Prog Ser 146:249-264

Egge JK, Aksnes DL (1992) Silicate as regulating nutrient in phytoplankton competition. Mar Ecol Prog Ser 83:281-289

Emery BM, Washburn L, Harlan JA (2004) Evaluating radial current measurements from CODAR high-frequency radars with moored current meters. J Atmos Ocean Technol 21:1259-1271

Evans KM, Kuhn SF, Hayes PK (2005) High levels of genetic diversity and low levels of genetic differentiation in North Sea Pseudo-nitzschia pungens (Bacillariophyceae) populations. J Phycol 41:506-514

Fehling J, Davidson K, Bolch CJ, Bates SS (2004) Growth and domoic acid production by Pseudo-nitzschia seriata (Bacillariophyceae) under phosphate and silicate limitation. J Phycol 40:674-683

Fritz L, Qulliam MA, Wright JLC, Beale AM, Work TM (1992) An outbreak of domoic acid poisoning attributed to the pennate diatom Pseudonitzschia australis. J Phycol 28: 439-442

Fryxell GA, Villac MC, Shapiro LP (1997) The occurrence of the toxic diatom genus Pseudo-nitzschia (Bacillariophyceae) on the west coast of the USA, 1920-1996: a review. Phycologia 36:419-437

Garrison DL (1981) Monterey Bay phytoplankton. II. Resting spore cycles in coastal diatom populations. J Plankton Res 3:137-156

Garrison DL, Conrad SM, Eiles PP, Waladron EM (1992) Confirmation of domoic acid production by Pseudonitzschia australis (Bacillariophyceae) cultures. J Phycol 28:604-607

Hallegraeff GM (1993) A review of harmful algal blooms and their apparent global increase. Phycologia 32:79-99

Harms S, Winant CD (1998) Characteristic patterns of the circulation in the Santa Barbara Channel. J Geophys Res 103:3041-3065

Hasle GR (1978) The inverted-microscope method. In: Sournia A (ed) Phytoplankton manual. UNESCO, Paris, p 88-96

Johnson KS, Petty RL, Thompsen J (1985) Flow injection analysis for seawater macronutrients. In: Zirino A (ed) Mapping strategies in chemical oceanography, Vol 209. American Chemical Society, Washington, DC, p 7-30

Knap AH, Michaels AF, Dow RL, Johnson RJ and 8 others (1993) BATS methods manual, Version 3. U JGOFS Planning Office, Woods Hole, MA

Kudela R, Cochlan W, Roberts A (2003a) Spatial and temporal patterns of Pseudo-nitzschia spp. in central California related regional oceanography. In: Steidenger KA, Landsberg JH, Tomas CR, Vargo GA (eds) Harmful algae 2002. Florida and Wildlife Conservation Commission, Florida Institute of Oceanography, and Intergovernmental Oceanographic Commission of UNESCO, St. Pete Beach, FL, p 347-349

Kudela R, Roberts A, Armstrong M (2003b) Laboratory analyses of nutrient stress and toxin production in Pseudo-nitzschia spp. from Monterey Bay, California. In: Steidenger KA, Landsberg JH, Tomas CR, Vargo GA (eds) Harmful algae 2002. Florida and Wildlife Conservation Commission, Florida Institute of Oceanography, and Intergovernmental Oceanographic Commission of UNESCO, St. Pete Beach, FL, p 136-138

Ladizinsky NL, Smith GJ (2000) Accumulation of domoic acid by the coastal diatom Pseudo-nitzschia multiseries: a possible copper complexation strategy. J Phycol 36 (Abstract) Lange CB, Reid FMH, Vernet M (1994) Temporal distribution 
of the potentially toxic diatom Pseudonitzschia australis at a coastal site in Southern California. Mar Ecol Prog Ser 104:309-312

Langlois G (2003) Marine biotoxin monitoring program annual report, 2002. California Department of Health Services for the California Department of Fish and Game, Sacramento, CA

Langlois G (2004) Marine biotoxin monitoring program annual report, 2003, California Department of Health Services for the California Department of Fish and Game, Sacramento, CA

Maldonado MT, Hughes MP, Rue EL, Wells MC (2002) The effect of $\mathrm{Fe}$ and $\mathrm{Cu}$ on growth and domoic acid production by Pseudo-nitzschia multiseries and Pseudo-nitzschia australis. Limnol Oceanogr 47:515-526

Marchetti A, Trainer VL, Harrison, PJ (2004) Environmental conditions and phytoplankton dynamics associated with Pseudo-nitzschia abundance and domoic acid in the Juan de Fuca eddy. Mar Ecol Prog Ser 281:1-12

McClain CR, Pichel WG, Walton CC (1985) Comparative performance of AVHRR-based multichannel sea surface temperatures. J Geophys Res C 90:11587-11601

McClain CR, Feldman GC, Hooker SB (2004) An overview of the SeaWiFS project and strategies for producing a climate research quality global ocean bio-optical time series. In: Siegel DA, AC Thomas, J Marra (eds) Views of ocean processes from the sea-viewing wide field-of-view sensor (SeaWiFS) mission: Vol 2, Vol 51. Pergamon-Elsevier Science, Oxford, p 5-42

Mengelt C (2006) How two species of the diatom Pseudonitzschia respond to adverse conditions: $P$. australis and $P$. multiseries UV-photoecology, dark survival, and seasonal abundance at two coastal sites in Central California. PhD dissertation, University of California, Santa Barbara

Miller PE, Scholin CA (2000) On detection of Pseudonitzschia (Bacillariophyceae) species using whole cell hybridization: sample fixation and stability. J Phycol 36: 238-250

Nishimoto MM, Washburn L (2002) Patterns of coastal eddy circulation and abundance of pelagic juvenile fish in the Santa Barbara Channel, California, USA. Mar Ecol Prog Ser 241:183-199

Oey LY, Wang DP, Hayward TL, Winant CD, Hendershott M (2001) "Upwelling" and "cyclonic" regimes of the nearsurface circulation in the Santa Barbara Channel. J Geophys Res C 106:9213-9222

Orsini L, Procaccini G, Sarno D, Montresor M (2004) Multiple rDNA ITS-types within the diatom Pseudo-nitzschia delicatissima (Bacillariophysceae) and their relative abundances across a spring bloom in the Gulf of Naples. Mar Ecol Prog Ser 271:87-98

Otero MP, Siegel DA (2004) Spatial and temporal characteristics of sediment plumes and phytoplankton blooms in the Santa Barbara Channel. Deep-Sea Res II 51:1129-1149

Pan Y, Subba Rao DV, Mann KH, Brown RG, Pocklington R (1996a) Effects of silicate limitation on production of domoic acid, a neurotoxin, by the diatom Pseudo-nitzschia multiseries. I. Batch culture studies. Mar Ecol Prog Ser 131:225-233

Pan Y, Subba Rao DV, Mann KH, Li WKW, Harrison WG

Editorial responsibility: Howard Browman (Associate Editorin-Chief), Storebø, Norway (1996b) Effects of silicate limitation on production of domoic acid, a neurotoxin, by the diatom Pseudo-nitzschia multiseries. II. Continuous culture studies. Mar Ecol Prog Ser 131:235-243

Pan Y, Bates SS, Cembella AD (1998) Environmental stress and domoic acid production by Pseudo-nitzschia: a physiological perspective. Nat Toxins 6:127-135

Pocklington R, Milley JE, Bates SS, Bird CJ, de Freitas ASW, Quilliam MA (1990) Trace determination of domoic acid in seawater and phytoplankton by high-performance liquid chromatography of the fluorenylmethoxycarbonyl (FMOC) derivative. Int J Environ Anal Chem 38:351-368

Rue EL, Bruland KW (2001) Domoic acid binds iron and copper: a possible role for the toxin produced by the marine diatom Pseudo-nitzschia. Mar Chem 76:127-134

Scholin CA, Gulland F, Doucette GJ, Benson S and 22 others (2000) Mortality of sea lions along the central California coast linked to a toxic diatom bloom. Nature 403:80-83

Sommer U (1994) Are marine diatoms favoured by high Si:N ratios? Mar Ecol Prog Ser 115:309-315

Smayda TJ (1990) Novel and nuisance phytoplankton blooms in the sea: evidence for a global epidemic. In: Granéli E (ed) Toxic marine phytoplankton: Fourth International Conference, Lund, Sweden, June 26-30, 1989, Vol 21. Elsevier Science, New York, p 29-40

Smayda TJ (1992) Global epidemic of noxious phytoplankton blooms and food chain consequences in large ecosystems. In: Sherman K, Alexander LM, Gold BD (eds) Food chains, yelds, models, and management of large marine ecosystems. Westview Press, Boulder, CO, p 276-307

Trainer VL, Adams NG, Bill BD, Stehr CM, Wekell JC, Moeller PDR, Busman M, Woodruff D (2000) Domoic acid production near California coastal upwelling zones, June 1998. Limnol Oceanogr 45:1818-1833

Trainer VL, Hickey BM, Horner RA (2002) Biological and physical dynamics of domoic acid production off the Washington coast. Limnol Oceanogr 47:1438-1446

Turner RE, Qureshi N, Rabalais NN, Dortch Q, Justic D, Shaw RF, Cope J (1998) Fluctuating silicate:nitrate ratios and coastal plankton food webs. Publ Nebraska Acad Sci 95: 13048-13051

Wells ML, Trick CG, Cochlan WP, Hughues MP, Trainer VL (2005) Domoic acid: the synergy of iron, copper, and the toxicity of diatoms. Limnol Oceanogr 50:1908-1917

Wilkerson FP, Dugdale RC (1987) The use of large shipboard barrels and drifters to study the effects of coastal upwelling on phytoplankton dynamics. Limnol Oceanogr 32:368-382

Winant CD, Dever EP, Hendershott MC (2003) Characteristic patterns of shelf circulation at the boundary between central and southern California. J Geophys Res C 108:3041-3066

Wright JLC, Quilliam MA (1995) Methods for domoic acid, the amnesic shellfish poisons. In: Hallegraeff GM, Anderson DM, Cembella AD (eds) IOC manual on harmful algae, IOC manuals and guides Vol No. 33. UNESCO, Paris, p 113-133

Zimmerman RC, Kremer JN, Dugdale RC (1987) Acceleration of nutrient uptake by phytoplankton in a coastal upwelling ecosystem: a modeling analysis. Limnol Oceanogr 32: 359-367

Submitted: October 10, 2005; Accepted: March 14, 2006

Proofs received from author(s): November 22, 2006 